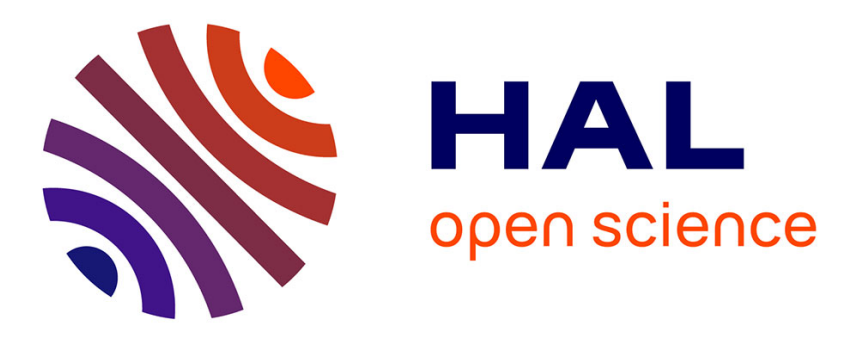

\title{
Centenary of the death of Elie Metchnikoff: a visionary and an outstanding team leader.
}

Jean-Marc Cavaillon, Sandra Legout

\section{To cite this version:}

Jean-Marc Cavaillon, Sandra Legout. Centenary of the death of Elie Metchnikoff: a visionary and an outstanding team leader.. Microbes and Infection, 2016, 18 (10), pp.577-594. 10.1016/j.micinf.2016.05.008 . pasteur-01469399

\section{HAL Id: pasteur-01469399}

\section{https://hal-pasteur.archives-ouvertes.fr/pasteur-01469399}

Submitted on 16 Feb 2017

HAL is a multi-disciplinary open access archive for the deposit and dissemination of scientific research documents, whether they are published or not. The documents may come from teaching and research institutions in France or abroad, or from public or private research centers.
L'archive ouverte pluridisciplinaire HAL, est destinée au dépôt et à la diffusion de documents scientifiques de niveau recherche, publiés ou non, émanant des établissements d'enseignement et de recherche français ou étrangers, des laboratoires publics ou privés.

$$
\text { Copyright }
$$



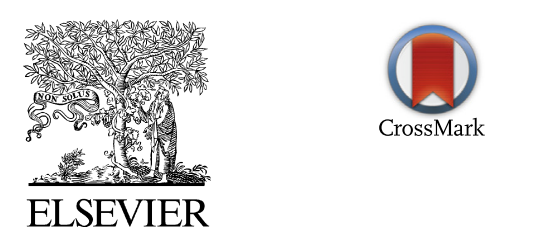

Institut Pasteur

Microbes and Infection 18 (2016) 577-594

Review

\title{
Centenary of the death of Elie Metchnikoff: a visionary and an outstanding team leader
}

\author{
Jean-Marc Cavaillon $^{\mathrm{a}, *}$, Sandra Legout ${ }^{\mathrm{b}}$ \\ ${ }^{a}$ Unit Cytokines \& Inflammation, Institut Pasteur, 28 Rue Dr. Roux, 75015 Paris, France \\ ${ }^{\mathrm{b}}$ Centre de Ressources en Information Scientifique, Institut Pasteur, 28 Rue Dr. Roux, 75015 Paris, France
}

Received 22 April 2016; accepted 26 May 2016

Available online 7 June 2016

\begin{abstract}
Elie Metchnikoff passed away on July 15th, 1916. He is considered to be the father of phagocytes, cellular innate immunity, probiotics, and gerontology. In all of these fields, he was a visionary. To achieve such a notability and produce so many masterpieces, Metchnikoff used more than 30 animal species to support his findings, and his pasteurian laboratory published more than 200 papers in the Annales de l'Institut Pasteur. As a wonderful team leader and a great mentor, during his 28 years at Institut Pasteur, he welcomed and supervised more than 100 young trainees. Trained as an embryologist, he contributed to the birth of immunology and to the understanding of physiology and pathology. Indeed, Metchnikoff and his team investigated inflammation in guinea pigs, rats, frogs; studied infectious diseases in monkeys, caimans, geese; investigated aging in parrots, dogs, humans; proposed hypotheses to understand age-associated senility using rabbits and humans; developed germ free tadpoles, flies, chicks; studied the gut flora in bats, horses, birds, humans; and popularized the use of probiotics as a tool to delay the deleterious effects of toxic compounds derived from putrefactive gut bacteria. He was also a philosopher and penned essays on human disharmony and on pessimism and optimism.
\end{abstract}

(C) 2016 Institut Pasteur. Published by Elsevier Masson SAS. All rights reserved.

Keywords: Phagocytes; Macrophages; Gerontology; Microbiota; Aging; Probiotic

\section{The centenary of Elie Metchnikoff's death}

Hundreds of articles and numerous books have already been published on Elie Metchnikoff, and historians have attempted to critically examine his research in terms of its genesis, conceptual foundations, and scientific impact [1-4]. Thus, while we will include here information previously published about his life, career, and contributions [5-13], we will offer new perspectives on his numerous investigations through the publications of collaborators who were working in his laboratory. For the centenary of the death of this giant, "Microbes and Infection", which is the descendent of the Annales de l'Institut Pasteur, wished to pay tribute to this great

\footnotetext{
* Corresponding author.

E-mail address: jean-marc.cavaillon @ pasteur.fr (J.-M. Cavaillon).
}

scientist. This is all the more remarkable because Metchnikoff was a member of the editorial board of the Annales de l'Institut Pasteur from 1890 to his death in 1916, and Metchnikoff and his numerous lieutenants, the members of his laboratory, published more than 200 papers in the Annales de l'Institut Pasteur. Amazingly, around one hundred trainees and colleagues from all around the world published in the Annales de l'Institut Pasteur acknowledging the work as "from the laboratory of E. Metchnikoff". This was a different period in research, when trainees did not fight to be the 3rd or 4th coauthor, when the head of the laboratory did not consider putting his name as senior author, when scientists were not concerned with impact factor and instead published their most important discoveries in their most friendly journal. In all of these reports, the large number of animal species Metchnikoff and his lieutenants used is striking. Like most of their colleagues, by the end of nineteenth century, they rarely used 
mice. Instead, they worked with species such as dogs, pigeons, rabbits, donkeys, pigs, guinea pigs, bighorn sheep, or even foxes. This was indeed fortunate, because Bernard Gaspard (1788-1871), François Magendie (1783-1855), Stéphane Tarnier (1828-1897), Saturnin Arloing (1846-1911), Victor Feltz (1835-1893), Léon Coze (1819-1896), Carl J. Salomonsen (1847-1924), and Nikolai F. Gamaleia (1859-1949), who contributed to the demonstration of the relationship among putrefaction, bacteria, microbial products, sepsis and death, would have failed to do so if they had been working with mice, which are highly resistant to bacterial products and sepsis [14]. When M. Cahanesco from Romania studied the bacterial vaginal flora in Metchnikoff's lab, he noticed that Staphyloccous aureus could kill rabbits and guinea pigs upon intreaperitoneal injection but giant diplodococcus did not harm mice [15]. In 1888, Metchnikoff sent a letter to Duclaux about a controversial issue he had with George Nuttall (1862-1937): "Finally, regarding the choice of the animals to use for the experiment, you [Duclaux] believe that Mr. Nuttall was wrong to choose mice to test the strength of the anthrax virus, but you have not noticed, I believe that he seeks to demonstrate the inaccuracy of my results on the loss of virulence in rabbits by experiments made with mice."

Elie Metchnikoff was 71 when he was transferred from the hospital of Institut Pasteur to Louis Pasteur's apartment after his health seriously deteriorated due to heart disease. He told Dr. Roux "See how my life is bound with Institut Pasteur. I have worked here for years; I am nursed here during my illness; in order to complete the connection, I ought to be incinerated in the great oven where our dead animals are burnt, and my ashes could be kept in an urn in one of the cupboards in the library" [16]. Emile Roux, the director of Institut Pasteur thought it was a gruesome joke, but Olga, his wife, confirmed the last will of her husband. On July 15th 1916, at 5:30 pm, Metchnikoff took his last breath after 28 years at Institut Pasteur where he had been deputy-director since 1904 (Fig. 1). He, the pacifist, was dying the day after the celebration of the Bastille day, when French soldiers were marching in Paris before going back to the war front. Obituaries were published in numerous famous scientific journals such as The Chemical News and Journal of Physical Science, The British Medical Journal, The Lancet, La Presse Médicale, the Annales de l'Institut Pasteur, and also in the lay press as in the front page of "Le Figaro", and also in the United States or in Russia. His popularity remained strong as illustrated by a whole page in the New York Times (April 30th, 1922) after his biography, written by his wife, was translated into English. Part of his popularity was due to his investigation of the use of probiotics to limit the effects of aging. On January 1910, Charles J. Brandreth after having visited him, wrote a spectacular article in the London Magazine about "The man who prolongs life" [17]. Brandreth wrote, "It is interesting to note how Metchnikoff was able to demonstrate the effect on the system of the putrefactive microbes. From the dejections of aged and decrepit persons he extracted the putrefactive microbes, and prepared an "intensified" culture which, he proceeded to inject into the system of a number of young gorillas and baboons. The result was remarkable and conclusive, for within a very short space of time the animals began to show all the signs of decrepitude and old age, and died from pre-mature senility". Brandreth made an accurate description of the scientist. "His head was covered with a wild, unkempt mass of hair, which, with a quick, impatient movement of his long, thin hands, he kept brushing back from his broad forehead. A pair of large, round spectacles bridged a very prominent nasal organ, and through the glasses there sparkled two of the brightest, keenest eyes I have ever seen. His features twitched with much inward excitement, and from his chin there fell a long, straggling beard plentifully streaked with grey." No doubt that Brandreth fell in love, "Ilias Metchnikoff is certainly "possessed," but not with an evil demon. The spirit that transfigures him, that makes itself felt in his clear brain, his bright eye, and his harmonious and illuminating speech, is the noble genius of science applied to the cause of the human race." To support his enthusiasm, he quoted Max von Gruber (1853-1927), an Austrian bacteriologist who discovered specific agglutination: "Metchnikoff would seem to have been specially created for the sole purpose of making fruitful scientific discoveries, but he is far more than a prominent scientist; he is a great and good man, one of the loveliest incarnations of those enthusiastic beings so frequently to be found amongst his own race -Slavs. Metchnikoff is an embellishment to mankind."]. Constantin Levaditi, who worked with Metchnikoff, further defined the character: "Convinced pacifist, for him, life had only one goal: scientific research. My master lived in a world apart, made of art and philosophy, for which the discovery of novelties was dominant. Musician, he was at the bottom of his soul. He also loved painting ... Outstanding character, scientist of genius, scholar, a tireless researcher, philosopher also and above all Slavic to the end of his soul." Emile Roux was a colleague, a close friend and an admirer of Metchnikoff, as well. For his jubilee, Roux stated: "The institute owes you much, you brought the prestige of your reputation, and your work and that of your students have greatly contributed to its glory". [18].

Another description was given by Alexandre Besredka (1870-1940) in his book published in 1921 entitled "The story of an idea - The works of Elie Metchnikoff". Alexandre Besredka was from Odessa and made a great career at Institut Pasteur after he joined Metchnikoff's laboratory. ${ }^{1}$ Having returned from World War I, Besredka succeeded Metchnikoff and took over the laboratory of his mentor. In July 1916, he

\footnotetext{
${ }^{1}$ Interestingly Metchnikoff asked Besredka to undertake medical studies before joining the lab. This demonstrates that Metchnikoff, like Pasteur, supported the complementarity of the two professional tracts of research and medicine, despite the fact that they themselves were not physicians. They fully supported Charles Richet (1850-1935), Nobel prize winner in 1913 for his discovery of anaphylaxis, when he stated in 1888 during his inaugural lecture at the Paris Medical School: "To oppose the physician to the physiologist and the scientist to the clinician, means that one has understood neither physiology nor medicine." Of note, Besredka is considered as the father of desensitization to prevent anaphylatoxic reaction, but he also did key experiments in the field of immunity to bacteria when he obtained the very first anti-endotoxin antibodies in the world [19].
} 


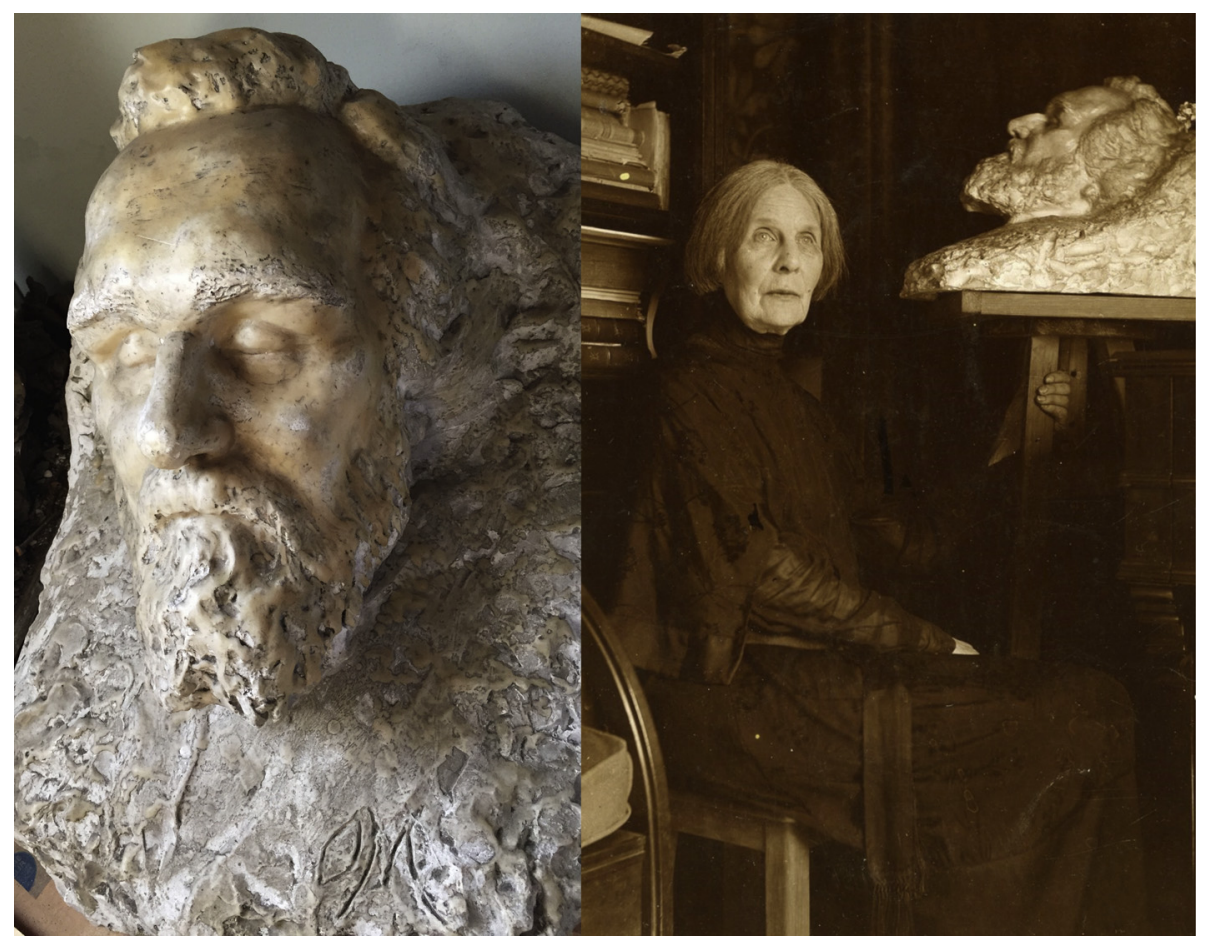

Fig. 1. Death mask of Metchnikoff made by his wife, Olga (1916), and Olga in front off this mask (1939).

was in the military hospital of Bar-Le-Duc tending to the numerous wounded soldiers from the Battle of Verdun. Upon receiving the news of Metchnikoff's death, Besredka reflected with other physicians, "Those who had the opportunity to approach Metchnikoff recall his original face, already foretelling the legend, now among the most popular of Paris; his heavy walking, all of a block, rolling, giving the impression of will and force; his eyes sheltered behind spectacles, sparkling with mischief and kindness; his simplicity, his invariably welcoming attitude. Others praise his erudition and the prodigious memory that made Metchnikoff a live encyclopedia, enticing you to browse through especially when doing so, you pleased him. Some point out his teacher talent, exerting an inescapable grip on his audience; and the juvenile ardor he brought to the discussions in academia and especially at international congresses, his fiery temper feared by his opponents" [20] (Fig. 2).

Elie Metchnikoff was born on May 15th, 1845, in a village former called Ivanovka in Russia, which is now Kupiansk Raion in Ukraine, $135 \mathrm{~km}$ southeast from Kharkov. His father was Ilya Ivanovich Metchnikov (1810-1878), an officer of the Imperial Guard. His mother was Emilia born Nevahovna (1814-1879), the daughter of Leo Nevahovitch, a Jewish writer and former Farmer-General for tobacco in Poland who had adopted the Lutheran religion and brought up his children in it. Elie was the youngest child of the family with one sister Catherine (born 1834), and three brothers, Ivan (born 1836), Leo (born 1838), and Nicholas (born 1843).

He was a bright student who learnt German at the age of 15 to be able to read German authors. At 17, he read the book of Darwin on species evolution that greatly influenced his thinkings [21]. After his studies at the high school of Kharkov, he decided to travel. He was 19 when he went to Germany and Italy, visiting and studying in Heligoland, an island West of Hamburg; joined Rudolf Leuckart (1822-1898) at the University of Giessen, where he discovered intracellular digestion in a flatworm; went to Munich and met Karl Theodor Ernst von Siebold (1804-1885), a German physiologist and zoologist; and finally ended his journey in Naples with Alexander Kovalevsky (1840-1901), a Russian embryologist, where he began his doctoral thesis on embryonic development of cuttlefish and crustaceans. In 1867, he defended his thesis and obtained his doctorate in Science. In 1869, he was appointed Professor at Saint-Petersburg University and in 1870 he was made Zoology professor at Odessa University. In 1869, he married Ludmila Vassilievna Fedorovna. She was already suffering from tuberculosis; he got scientific missions and they traveled to Vilius, La Spezzia, Montreux, San Remo, Villefranche, Saint Vaast; Normandy, before moving to Madera in search of restorative air for her. She died there in 1873 after four years of indescribable suffering. Widower at the age of 28, Metchnikoff was desperate and on his way back to Odessa, in Geneva, he attempted to kill himself, swallowing a large dose of the morphine his wife was using to limit her pain. He did not die, however he continued to use morphine to overcome his pessimistic view of life for some time, until intoxication ended its use, a confession he made in his book on pessimism and optimism [22].

Back at the University of Odessa, he worked as a professor of zoology and comparative anatomy. He gave private lessons and subsequently met a young student named Olga Belokopytova. She was living with her family of eight children in the 


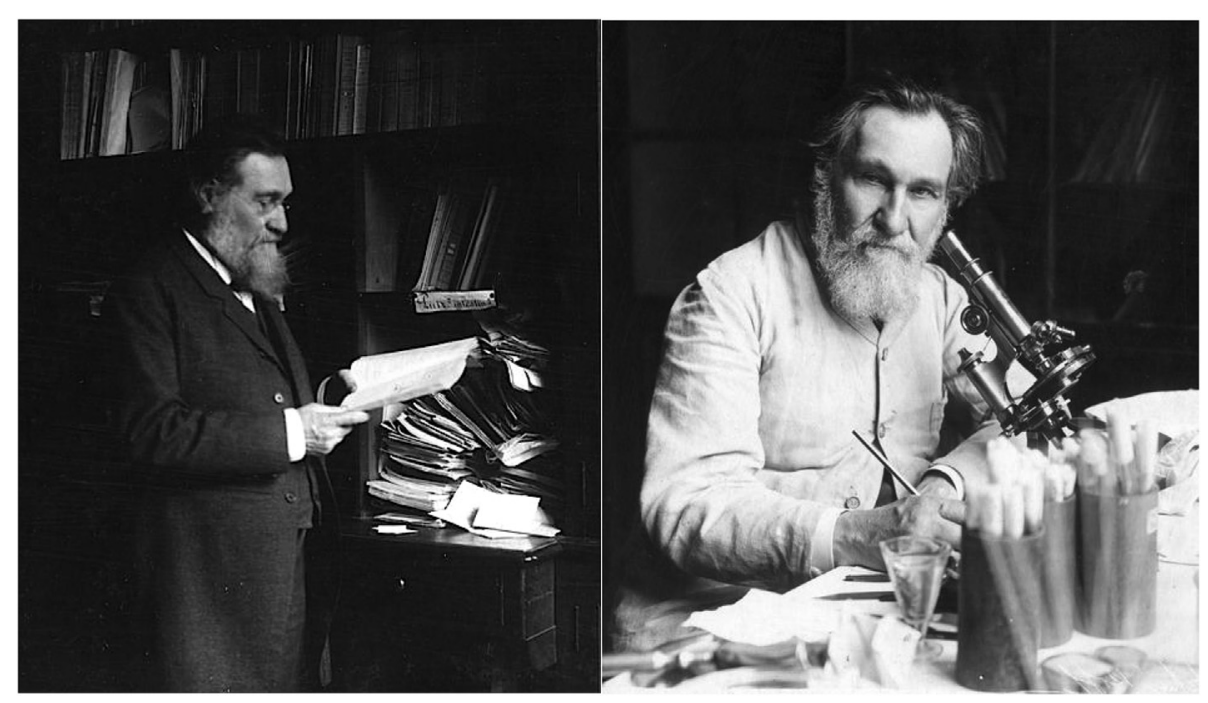

Fig. 2. Metchnikoff in his office and at the bench (1910).

same house as Metchnikoff. He married her in 1874 when she was 17, thirteen years younger than him (Fig. 3). In 1880, she developed typhoid fever. Ever more depressed and having health problems with his eyes and heart, Elie Metchnikoff attempted again to kill himself. This time, he injected himself with the blood of a patient with relapsing fever. Remarkably, this act demonstrated that the disease was transmissible since he became severely ill, but fortunately did not die. Metchnikoff performed another experiment on himself, related by Jean Cantacuzène in his medical thesis (1894), which was not designed to induce death but to demonstrate the safety of the administration of Vibrio cholera per os after alkalinization of the stomach. Following the success of the experiment, others agreed to repeat it. Few had diarrhea and only one was severely sick and developed the symptoms of cholera.

In 1885, Metchnikoff was nominated to be director of the new bacteriology institute founded by the city of Odessa to focus on rabies vaccination. Soon he resigned from this position in search of another place to work. He met Louis Pasteur in Paris and Robert Koch in Berlin. Pasteur offered to welcome him to his new institute, which was being built, whereas Koch received him very coldly, unconvinced by the

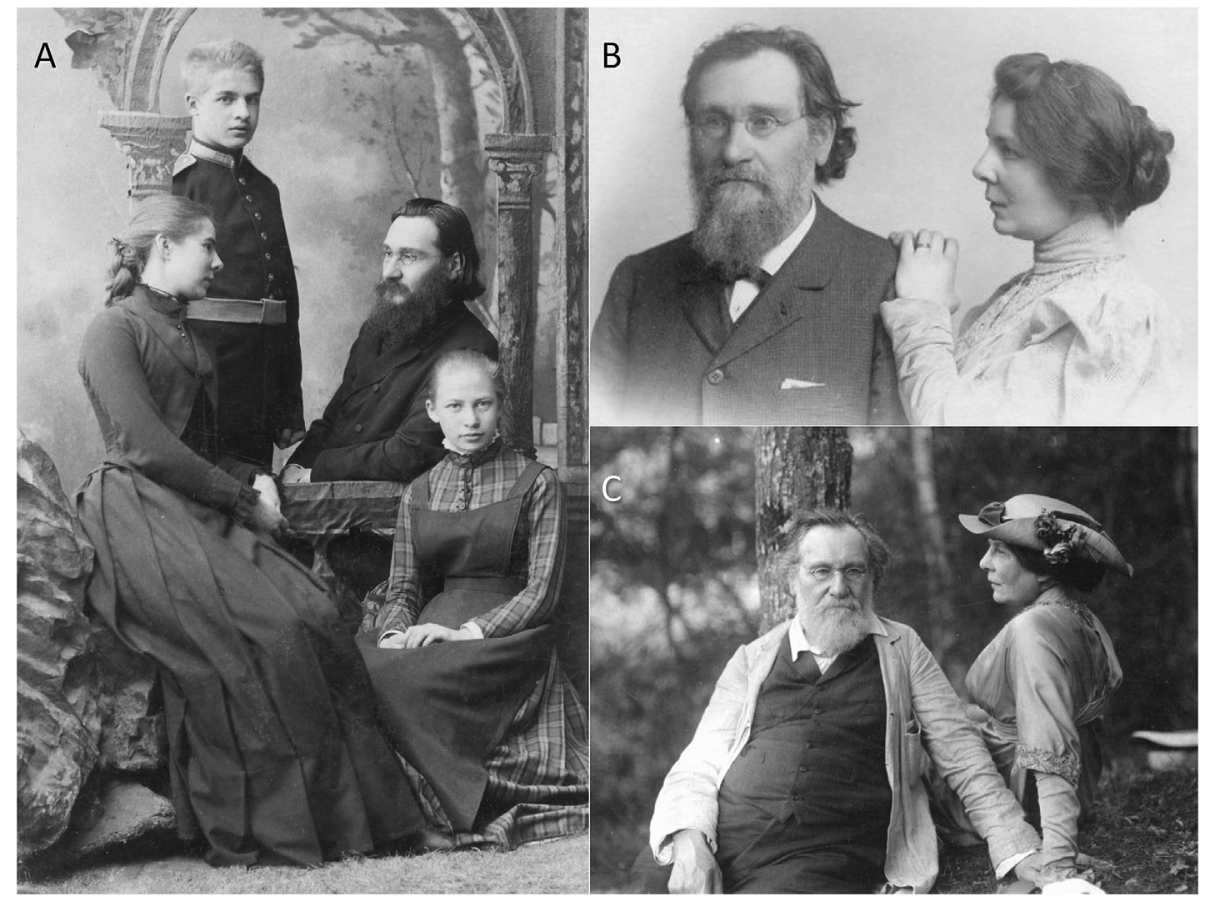

Fig. 3. Portrait of Elie Metchnikoff and Olga in 1887 (a), 1905 (b), and 1914 (c). Of note is the similar pose of Olga, in profile, looking at her husband while her husband is facing the camera. (Photos (a) \& (b) have been kindly provided by the Russian Academy of Science). 
relevance of his work on phagocytosis. Metchnikoff was offered the position of head of the "morphologic microbia" unit at Institut Pasteur. He joined the opening of the Institut in 1888 with two medical doctors, Joseph Grancher and Emile Roux, and two graduates from École Normale Supérieure where Pasteur had been working previously, Emile Duclaux and Charles Chamberland. Although the young couple were a bit reluctant to live in Paris, they were impressed by the atmosphere described in Emile Zola's books and settled well. The first lived in a small house, called "the dacha," on the Institut Pasteur campus. In 1898, with inheritance money from an old aunt, they bought a villa in Sèvres where they spent their summers, before definitively living in this house from 1905. Metchnikoff was nominated deputy-director in 1904 and worked with Dr. Emile Roux (1853-1933). On May 6th, 1909 he sent a letter of resignation from his position to the President of the Administrative Council, arguing he had too many collaborators. It seems that his request was not taken into consideration since he remained deputy-director until his death.

Olga was an extremely gifted scientist, as well, and when they joined the Institut Pasteur, she worked in the laboratory and published two interesting studies, one of which described the very first germfree tadpoles [23]. She was very helpful in welcoming the numerous Russian trainees (Fig. 4) that came to Institut Pasteur and made wonderful paintings, including elegant portraits of her husband (Fig. 5). She accompanied him all along his life with devoted admiration [16]. She undertook nurse training at the beginning of World war I and got French citizenship in 1928. She died at the Hospital of Institut Pasteur in 1944.
As an active scientist, Metchnikoff traveled to international meetings held throughout Europe (Fig. 6), regularly, including to the International Congress of Hygiene. After joining the Institut Pasteur, Metchnikoff traveled seven times to Russia $(1889,1890,1892,1894,1902,1909,1911)$. The last trip was to the Kamoulk steppes (West of the river Volga and the Caspian sea) to carry out an epidemiological investigation on tuberculosis. Among the 1843 adults and children on whom the von Pirquet test (scarification with tuberculin) was performed, a great majority were positive [24]. As an admired teacher, he contributed every year to the great "Microbie" course given at Institut Pasteur since its opening in 1890. The career of Metchnikoff was accompanied by numerous awards and honors from all around the world (Table 1). Not only was Metchnikoff a great scientist and teacher and his laboratory the most appealing lab by the end of the nineteenth century; he was a beloved master, a thinker, and a philosopher who wrote two books: "Étude sur la Nature humaine: Essai de philosophie optimiste" (The nature of man: studies in optimistic philosophy), and "Essais optimistes", translated in English with a far more attractive title: "The prolongation of life: optimistic studies" [22,25].

\section{The masterpiece: the understanding of phagocytosis}

The main discovery of Metchnikoff is not the phagocytosis phenomenon per se, but the understanding of the phenomenon. Indeed, numerous scientists had observed and reported the process before him, and had even hinted at its underlying function:

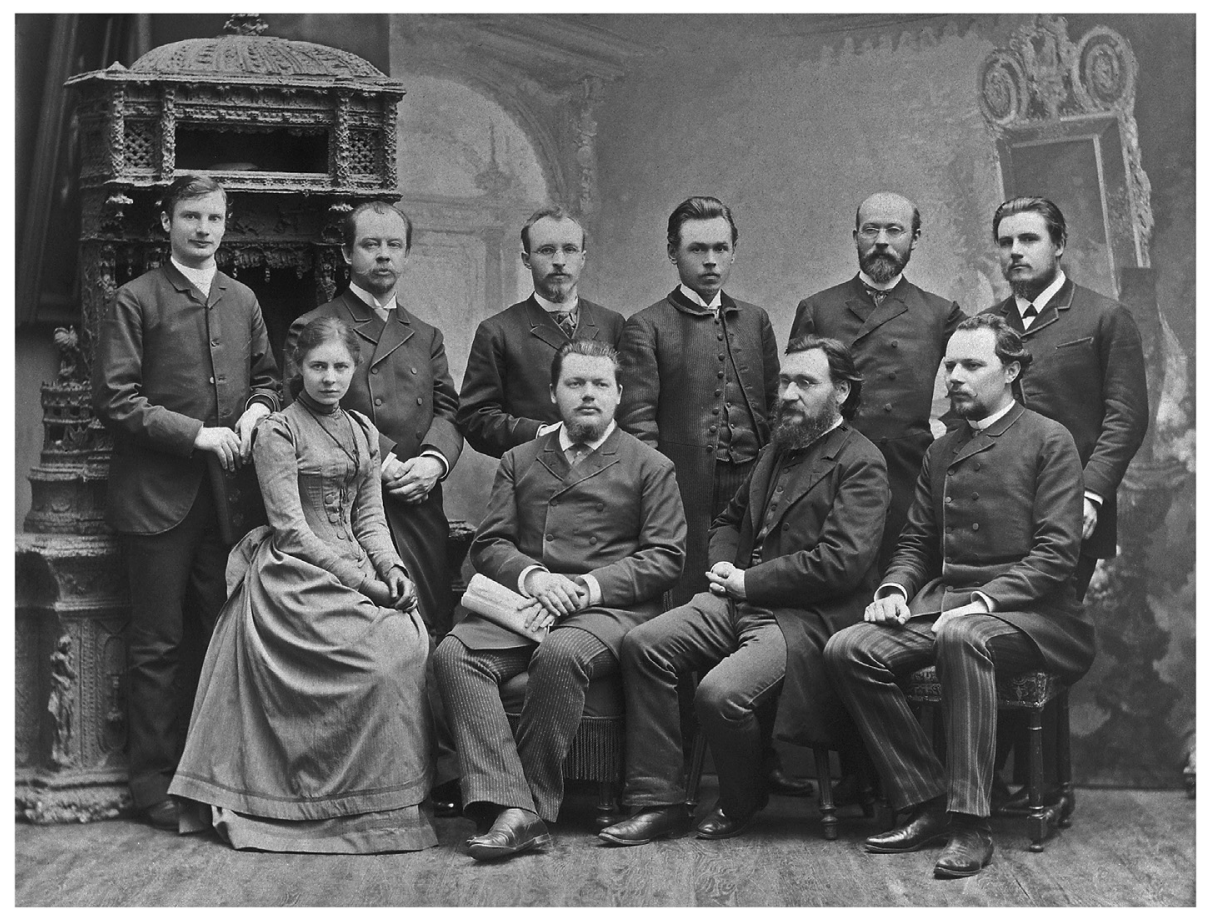

Fig. 4. Metchnikoff's lab staff in 1890. Standing from left to right: WM Hafkine, T Trapeznikoff, G. Gabritchewsky, N Protopopoff, W Polowtzoff. Seated from left to right: Olga Metchnikoff, A Zamchine, Elie Metchnikoff, K Wagner. 


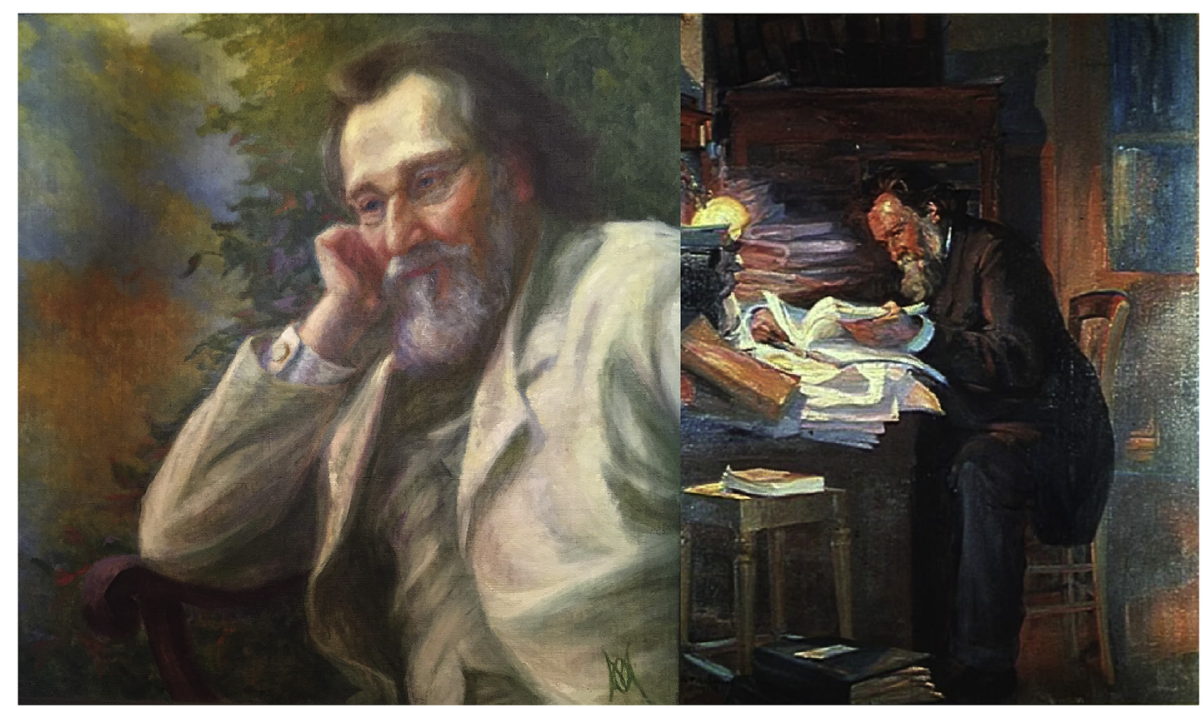

Fig. 5. Left, Beautiful portrait of Metchnikoff painted by Olga (Pauls Stradiņš Museum of the History of Medicine, Riga, Latvia). Right, portrait of Metchnikoff (1907) by Ossip Perelmanov, dit Ossy de Perelma (1876-1949), Russian artist (Musée de l'Institut Pasteur).

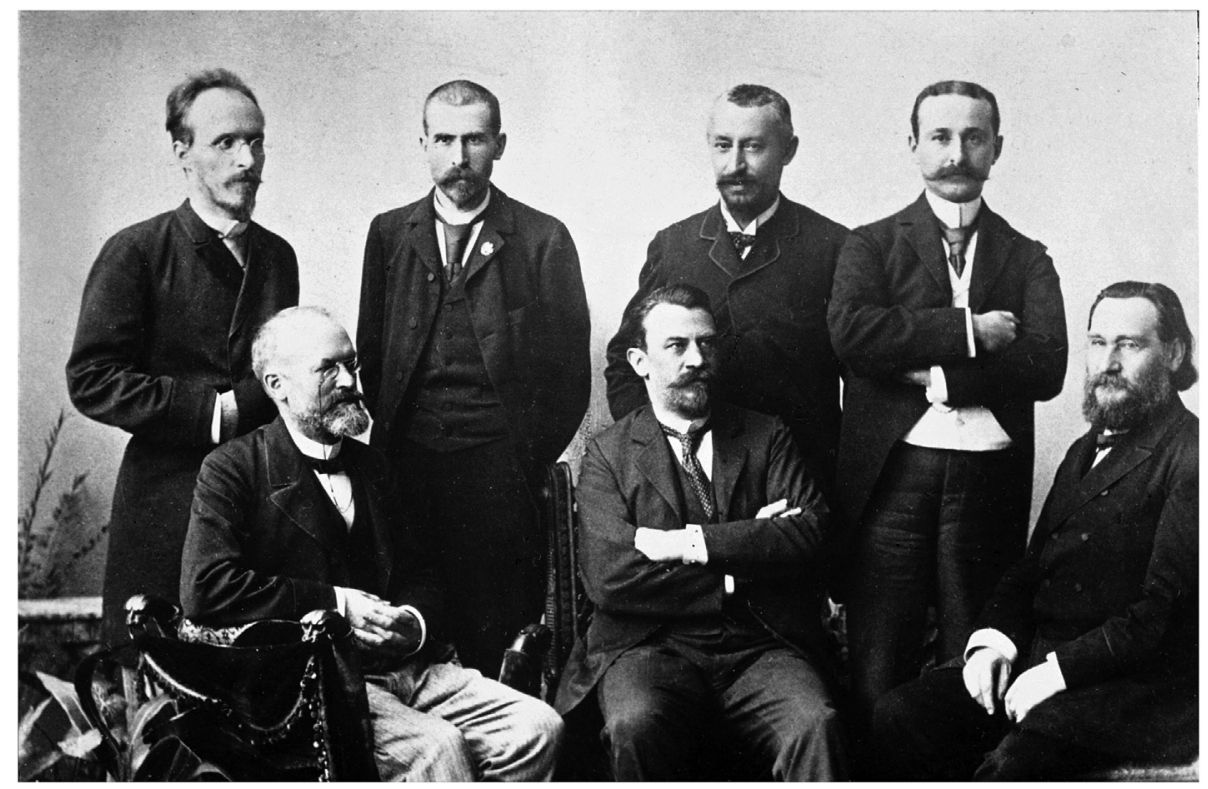

Fig. 6. Participants at the Budapest congress on diphteria in 1894. Seated from left to right: Lavéran, Pétrix, Metchnikoff. Standing from left to right: Gabritchewsky, Roux, Nocard, Nuttal.

- In 1847, Alexander Ecker (1816-1887), a German anthropologist and anatomist, described erythrocytes inside rabbit spleen cells [26].

- In 1870, Nathanael Lieberkühn (1821-1887), a German physician and anatomist, reported that leukocytes could ingest erythrocytes [27].

- In 1871, Giulio Bizzozero (1846-1901), an Italian professor of general pathology, provided the first pictures of macrophages that had ingested erythrocytes. Two years later he stated that reticular cells could ingest infective particles that were carried by the lymphatic liquid [28]. He was a pioneer when he made the appropriate hypothesis: “... this fact is, perhaps, the cause of the stoppage of some infections to the lymphatic glands which are connected to the part covered by the infection through the lymphatic vessels." [29].

- In 1874, Peter Ludwig Panum (1820-1885), a Danish physiologist and pathologist, also suggested that such cell ingestion might represent a method of defense [30].

- In 1875, Sir William Osler (1849-1919) a famous Canadian doctor described the intake of carbon particles within alveolar macrophages of miners [31]. 
Table 1

Awards honors and principal membership of Elie Metchnikoff.

\section{Awards and honors}

1867 Baer Prize shared with Alexander O. Kowalewsky (Russia) ${ }^{\text {a }}$

1881 Golden Medal Alexandre II.- Russian Society of Public Health (Russia)

1892 Chevalier (Knight) - Légion d'Honneur (France)

1895 Commandeur (Commander) - Order of St. Sava (Serbia)

1896 Officier (Officer) - Légion d'Honneur (France)

1901 Golden Wilde Medal - Literary and Philosophical Society (England)

1903 Order of the Rising Sun (Japan)

1903 Officier (Officer) of the Agricultural Order - Ministry of Agriculture (France)

1904 Benet Merenti Medal (1st Class) (Romania)

1906 Harben Gold Medal - Royal Institute of Public Health (England)

1906 The Copley Medal - Royal Society (England)

1907 First Class Medal - Physico-chemical Academy of Italy (Italia)

1908 Nobel Prize Medal, The Royal Karolinska Institute of Medicine and Surgery (Sweden)

1913 Commandeur (Commander) - Légion d'Honneur (France)

1914 The Cross of Sanitary Merit - (1st Class) (Roumania)

1916 Albert Medal - Royal Society of Arts (England)

Principal membership

1881 Honorary member - Society for the Protection of Public Health (St-Petersburg, Russia) ${ }^{\mathrm{b}}$

1883 Corresponding member - Imperial Academy of sciences (St. Petersburg, Russia)

1889 Honorary member - Imperial Moscow University (St. Petersburg, Russia) ${ }^{\mathrm{c}}$

1891 Corresponding member - Academy of Natural Sciences (Philadelphia, U.S.A.)

1891 Honorary degree of Doctor of science - University of Cambridge (Cambridge, England)

1891 Honorary member - Cambridge Philosophical Society (Cambridge, England)

1893 Associated member - Biological Society (Paris, France)

1894 Corresponding member - Royal Association of Medicine (Budapest, Austro-Hungary)

1895 Honorary member - Hungarian Society for Hygiene (Budapest, Austro-Hungary)

1895 Corresponding member - Italian Royal Society of Hygiene (Roma, Italia)

1898 Honorary member - American Academy of Arts and Sciences (Boston, U.S.A.)

1898 Honorary member - Society of Czech physicians (Prague, Austro-Hungary)

1900 Associated member - National Academy of Medicine (Paris, France)

1900 Honorary member - Societas Medicorum Fennica (Helsinski, Finland)

1901 Honorary Member - Literary and Philosophy Society (Manchester, England)

1902 Honorary member - Imperial Academy of sciences (St. Petersburg, Russia)

1903 Corresponding Foreign member - The Royal Academy of sciences (Turin, Italia)

1904 Associated member - Academy of sciences (Paris, France)

1904 Corresponding member - Academy of Sciences of Bologna Institute (Bologna, Italia)

1904 Honorary member - Imperial and Royal Society of Physicians (Vienna, Austro-Hungary)

1904 Corresponding member - Royal Society of medical and natural sciences (Brussel, Belgium)

1905 Associated member - Royal Society of medical and natural sciences (Brussels, Belgium)

1905 Associated member - Royal Academy of science, letters and fine Arts (Belgium, Brussels)

1905 Corresponding member - Society of Internal Medicine and Pediatrics (Vienna, Austro-Hungary)
1905 Honorary member - Society of Dermatology (Vienna, Austro-Hungary)

1906 Honorary member - Royal Institute of Public Health (London, Great Britain)

1906 Corresponding member - National Academy of medicine (Caracas, Venezuela)

1907 Honorary member - Physico-chemical Academy of Italy (Palerme, Italia)

1908 Honorary member - Society of Exotic Pathology (Paris, France)

1908 Honorary member - Society for Nature and Obstetrics (Dresden, Germany)

1908 Honorary member - The Riga Physicians Society (Riga, Latvia)

1909 Honorary member - Society for Microbiology (St. Petersburg, Russia)

1909 Honorary degree of Doctor of medicine - Military medical Academy (St. Pertesburg, Russia)

1909 Dr. Honoris Causa - Université Libre de Bruxelles (Belgium)

1909 Honorary member - Scientific Society "Antonio Alzate" (Mexico City, Mexico)

1910 Corresponding member - Royal Academy of sciences (Turin, Italia)

1911 Honorary member - Romanian Academy (Bucarest, Roumania)

1911 Honorary member - Imperial Academy of sciences (Vienna, austro-Hungary)

1912 Honorary member - Royal Society of medical and natural sciences (Belgium, Brussels)

1911 Honorary member - Serbian medical Society (Serbia, Belgrade)

1912 Honorary member - Royal Irish Academy (Dublin, Ireland)

1912 Honorary member - New-York Academy of science (New-York, U.S.A.)

1914 Corresponding member - Medical and Surgical Society (Bologna, Italia)

${ }^{a}$ Also in 1870 with A. Böttcher et Alexander O. Kowalewsky, and 1891 with W.W. Salensk.

b Also Honorary member from several Russian societies, Academies and Institutes: Saint-Petersburg: Society for the protection of Public Healt (1881), Society of Russian physicians (1883), Pediatric Society, Societas Medicorum Petropolitenorum, Society for Anatomy and Anthropology of Imperial Medical and Military Academy, The Society of Devotees of Natural sciences (1909), Psychiatric and neurological Institute (1909), Psychiatric Society (1911); Moscow: Veterinary medicine Society, The Muscovite Society of Dermatology and Venerology, The Ledenzoff Society for assisting discoveries and invention useful to humanity (1909), The Muscovite Scientific Institute (1912); Kiev: Natural science Society of Saint Vladimir University (1891), Agricultural Society (1901); Dorpat: The Pirigov Society (1911); Kasan: Veterinary medicine Society (1913). Russian societies of medicine: Simbirsk (1893), Ekaterinoslav (1897), Novgorod (1899), Podolsk (1905), Riga (1908), Nikolajev (1909), Kronstadt (Marine medicine - 1909), Kasan (1910), Simferopol (1911), Zaryzin (1911), Kransnojarsk (1911), Sebastopol (1913), Kursk (1913).

c Also honorary member from several Russian Universities: Kiev Univ. (1892), Saint-Petersbourg (1895), Kharkov (1900), Kharkov Veterinary Medicine Univ. (1901), The Imperial Univ. (1903), Kasan Veterinary Medicine Univ. (1907), Saint Petersburg Medical Military Academy (1908), Saint Petersburg Medical Institute for Women (1909), Moscow Agricultural Univ. (1909), Saint Petersbourg Univ. (1913) Kasan Univ. (1914), Saratov Univ. (1916), Kharkov Univ. (1916).

Sources: H. Zeiss (1932), R. M. Petrov, T. I. Ulyankina (1996), Paul Stradins Museum (Riga, 2016).

- In 1876, Robert Koch himself identified anthrax bacilli in white blood cells. Yet Koch had interpreted his finding to mean that bacterial pathogens had invaded the host [32].

- In 1877, Paul Albert Grawitz (1850-1932) a German pathologist, noted that mammalian leukocytes could seize fungi and thus might protect the host [33]. 
- In 1881, one year before the fundamental discovery of Metchnikoff, Wilhelm Roser (1817-1888) a German surgeon, expressed a hypothesis to explain the resistance of certain lower animals and plants to bacteria [34]. Quoted by Metchnikoff, he stated: "The immunity of animals and plants in good health is due, in my opinion, on: 1) the relative salt content of their humors; and 2) the property of their contractile cells to engulf the entering enemy".

- In 1881, Alexander Ogston (1844-1929) a British surgeon and bacteriologist described in drawings "[...] groups of cocci, mostly free, but sometimes in or on large nonnucleated masses of protoplasm" [35]. Ogston coined the word "Staphylococcus" the following year from the ancient Greek word staphyle meaning a bunch of grapes.

- Of note, George Miller Sternberg (1838-1915), a US army physician and surgeon and one of the very first USbased bacteriologists, claimed to have suggested the process of phagocytosis [1], however, suggestion is not demonstration. In his book "Bacteria" published in 1884, he wrote: "The writer has elsewhere suggested that the disappearance of the bacteria from the circulation, [...] may be effected by the white corpuscles, which, it is well known, pick up, after the manner of amoebae, any particles, organic or inorganic, which come in their way. And it requires no great stretch of credulity to believe that they may, like an amoeba, digest and assimilate the protoplasm of the captured bacterium, thus putting an end to the possibility of its doing any harm." But, influenced by the vision of Koch, and copying one of his figures in which large numbers of bacilli can be seen within white blood corpuscles, he offered another possibility: «In the case of a pathogenic organism, we may imagine that, when captured in this way, it may share a likely fate if the captor is not paralyzed by some potent poison evolved by it, or overwhelmed by its superior vigor and rapid multiplication. In the latter event, the active career of our conservative white corpuscle would be quickly terminated, and its protoplasm would serve as food for the enemy. It is evident that in a contest of this kind the balance of power would depend upon circumstances relating to the inherited vital characteristics of the invading parasite and of the invaded leucocyte."

In 1882 Metchnikoff, his wife, his sisters-in-law and brothers-in-law were staying in Messina (Sicily). Metchnikoff remembers that specific day: "One day when the whole family had gone to a circus to see some extraordinary performing apes, I remained alone with my microscope, observing the life in the mobile cells of a transparent starfish larva, when a new thought suddenly flashed across my mind. I felt so excited that I began striding up and down the room and even went to the seashore in order to collect my thoughts [...]. I was too excited to sleep that night in the expectation of the result of my experiment" [16]. His scientific description recalls his observation: "The reactive phenomena ensuing on artificial injuries may be readily observed in the much larger larvae, the
Binpinnaria Astrigera [...]. If a delicate glass tube, a rosethorn, or a spine of a sea urchin be introduced into one of these larvae, the amoeboid cells of the mesoderm collect around the foreign body in large masses easily visible with the naked eye". He shared his observation and conceptualization with Nicolaus Kleinenberg (1842-1897), a Baltic German zoologist who had founded the marine station at Messina where he was professor, and with a famous visitor, Rudolf Ludwig Carl Virchow (1821-1902), a German physician and biologist, and the father of the cellular theory. The later was convinced by Metchnikoff's preparation but advised him to proceed with the greatest prudence because the contemporary theory of inflammation was at the time the direct contrary to Metchnikoff's new definition. On his way back to Odessa, he met his friend Carl Friedrich Wilhelm Claus (1835-1899) in Vienna. Claus was a German professor of zoology, who invited him to publish his results in his journal [36], and even proposed that he coins the word "phagocyte". In 1883, the word appeared for the first time in the title of his publication [37]. In this publication, Metchnikoff described the role of phagocytes during the metamorphosis of tadpole to frog and the disappearance of the tail, including amoeboid cells containing fragments of nerves and muscular fibers. In addition, he reported the process of phagocytosis in vertebrates. He injected putrid blood in a frog and observed that blood white cells contained variable amounts of bacilli, particularly in the spleen. The following year, he published two additional articles about his work on the role of phagocytes in daphnia fighting fungal pathogens and in frogs exposed to anthrax bacilli $[38,39]$.

To understand how the concept emerged in his mind, it is useful to recall his initial studies in the field of embryology. Metchnikoff discovered that in planarians, hydrozoa, siphonophorae, craspedote medusa, and parenchymula larva, the digestive track is not a cecum but a massive parenchyma. $\mathrm{He}$ then realized that the digestion process can be undertaken by specialized cells. The concept of digestion performed by specific cells would become the common thread of his thoughts through the years, adapted to the different topics he investigated [20]. Furthermore, his initial darwinian vision of inflammation ended to a "theory based on the law of evolution according to which the properties that are useful to the organism survive, while those which are harmful are eliminated" [40].

His book "Immunity in infective diseases" first published in French in 1901, and translated into English in 1905 offers wonderful cartoons of phagocytic cells. In his own book on inflammation (An introduction to the study of pathology, 1907), John George Adami (1862-1926), vice-Chancellor of the University of Liverpool, wrote in his chapter on phagocytosis, "We owe the first satisfactory studies upon the properties to the long continued and wonderful series of researches upon phagocytosis, initiated by Metchnikoff [...] Metchnikoff directed attention to their peculiar properties of ingesting other leukocytes, and named them "Macrophages" (a barbarous but a convenient term) [...] One has but to read Metchnikoff's fascinating work on "L'immunité dans les 
maladies infectieuses", to be impressed with the extraordinary diversity and number of the researches in connection with various pathogenic organisms whereby the phenomena of phagocytosis have been established and confirmed."

\section{The struggle to impose the concept of phagocytosis with the help of his lieutenants}

To convince researchers of the concept of phagocytosis was not an easy task, particularly when the German school considered that the main defense mechanisms were due only to humoral immunity. Metchnikoff noted, “... The controversy about the phagocytosis could have killed me, or sooner permanently weakened me. Sometimes, (I remember such attacks of Lubarsch in 1889, and those of Pfeiffer in 1894) I was ready to get rid of life." During a stay in Zurich in summer 1890, Metchnikoff showed to Lubarsch slides for which the German scientist agreed that bacteria were indeed within cells.

Back from the International meeting in Budapest in 1894, he wrote a report in which he claimed: "Getting to the end of our survey, we have noted the victory of the cellular theory of immunity and the failure of the purely humoral theories, and pointed out this general result that immunity in infectious diseases, is due to the activity of living cells of the body. Among these elements, the main role must surely be attributed to the phagocytes." [41]. Alas, the victory was not yet fully achieved. In 1908 at the Berlin meeting, Robert Koch said: « The new acquisitions have ruined the foundation of the phagocytic theory and therefore they must give way to the humoral theory of immunity » [20]. ${ }^{2}$ Nevertheless, the Nobel Committee in its great wisdom declared that both humoral and cellular immunity were equally important when awarding the Nobel prize 1908 to both leaders Paul Ehrlich and Elie Metchnikoff. This final victory of Metchnikoff was obtained thanks to the contribution of his lieutenants who individually fought their German contradictors (Table 2).

Among the German opponents were Paul Clemence von Baumgarten (1848-1928) and Carl Weigert (1845-1904), two German pathologists whom Metchnikoff tried to convince that giant cells displayed phagocytic properties, through his publication on tuberculosis [42]. To reach such a conclusion, Metchnikoff studied the bacillus of Koch in sparrows, rabbits, ground squirrels found close to Odessa (Spermophilus guttalus), and human sputum. Baumgarten had declared, "The interpretation of Metchnikoff on leukocyte activity appears rather as the product of a rich imagination rather than the result of the objective observation of a researcher" [20]. In a model of anthrax infection of white rats, Metchnikoff fought Emil von Behring (1845-1917), the future first Nobel prize 1901 for serotherapy, and the Danish doctor John Carl Constant Beresford de Christmas-Dirckinck-Holmfeld (1860-1916). For Behring, the resistance of the white rats was only due to the alkalinity of the blood, which is too high

\footnotetext{
${ }^{2}$ Despite this struggle with Koch, Metchnikoff was a strong advocate for awarding the Nobel prize to Koch, until it was awarded in 1905.
}

Table 2

Some of Metchnikoff's collaborators.

\begin{tabular}{|c|c|}
\hline Year of publication & Collaborators \\
\hline \multicolumn{2}{|c|}{$\begin{array}{l}\text { Collaborators who contributed to the field of phagocytosis, efferocytosis } \\
\text { and pinocytosis }\end{array}$} \\
\hline 1888 & Nikolai Fedorovich Gamaleia, Russia (1859-1949) \\
\hline $1890 \& 1894$ & George Gabrichevsky, Russia (1860-1907) \\
\hline 1889 & Nicolaï Tchistovitch, Russia (1860-1926) \\
\hline $1890 \& 1892$ & Marc Armand Ruffer, UK (1859-1917) \\
\hline 1891 & Olga Metchnikoff, Russia (1858-1944) \\
\hline 1892 & Ivan Soudakevitch, Russia (1859-1896) \\
\hline 1893 & Giuseppe Sanarelli, Italia (1864-1940) \\
\hline \multirow[t]{3}{*}{1896} & Félix Mesnil, France (1868-1938) \\
\hline & Jules Bordet, Belgium (1870-1961) \\
\hline & Arthur Hugenschmidt, France (1862-1929) \\
\hline 1897 & Galileo Pierallini, Italia (?-?) \\
\hline 1898 & Ion Cantacuzino, Romania (1863-1934) \\
\hline 1900 & Nicolai P. Matschinsky, Russia (1859-?) \\
\hline \multirow[t]{3}{*}{1901} & Alexandre Besredka, Russia (1870-1940) \\
\hline & Constantin Levaditi, Romania (1874-1953) \\
\hline & Ivan M. Himmel, Russia (1871-?) \\
\hline $1905 \& 1906$ & Max Löhlein, Germany (1877-1921) \\
\hline 1906 & Yervante Manouélian, Armenian (1872-1948) \\
\hline \multicolumn{2}{|c|}{$\begin{array}{l}\text { Collaborators who contributed to the field of inflammation (fever, } \\
\text { chemotactism) }\end{array}$} \\
\hline 1888 & $\begin{array}{l}\text { Nikolai Fedorovich Gamaleia, Russia } \\
(1859-1949)\end{array}$ \\
\hline 1890 & Georges Gabritchevsky, Russia (1860-1907) \\
\hline 1896 & Arthur Hugenschmidt, France (1862-1929) \\
\hline \multicolumn{2}{|c|}{$\begin{array}{l}\text { Collaborators who contributed to the field of bacteriology and infectious } \\
\text { diseases }\end{array}$} \\
\hline 1893 & Amédée Borrel, France (1867-1936) \\
\hline 1897 & Paul Salmon, France (1869-1929) \\
\hline 1906 & Alexandre Besredka, Russia (1870-1940) \\
\hline 1910 & Charles Cantu, Romania (?-?) \\
\hline 1916 & Etienne Burnet, French (1873-1960) \\
\hline \multicolumn{2}{|c|}{ Collaborators who contributed to the field of microbiota } \\
\hline 1903 & $\begin{array}{l}\text { Proscovia Vassilievna Tsiklinsky, Russia/Ukraine } \\
(1859-1923)\end{array}$ \\
\hline 1910 & Eugène Wollman, France (1883-1943) \\
\hline & Sakaye Ohkubo, Japan $(?-1910)$ \\
\hline 1911 & Jean Choukevitch, Russia (?-?) \\
\hline \multicolumn{2}{|c|}{ Collaborators who contributed to the field of axenic animals } \\
\hline 1901 & Olga Metchnikoff, Russia/France (1858-1944) \\
\hline 1911 & Eugène Wollman, France (1883-1943) \\
\hline 1912 & Michel Cohendy, France (1873-1940) \\
\hline
\end{tabular}

to allow the development of the bacillus. Christmas interpreted the work to suggest that the bacilli were destroyed by purulent liquid without the help of cells. Metchnikoff sent slides to Christmas, which helped to convince him. Several authors reported different sensitivity of their experimental rats to tuberculosis. Therefore, Metchnikoff performed experiments with white rats he obtained from Russia, Berlin, Zurich, and Paris, and convincingly demonstrated that phagocytosis occured, principally by the microphages (neutrophils) [43].

Metchnikoff fought Rudolph Emmerich (1856-1914), a German bacteriologist known for his investigations on cholera: «Mr. Emmerich goes much further in his opposition. He says the release of leukocytes and their phagocytic role represents an error of Nature because phagocytes are unable to destroy microbes but only disseminate them in the body » [44]. 


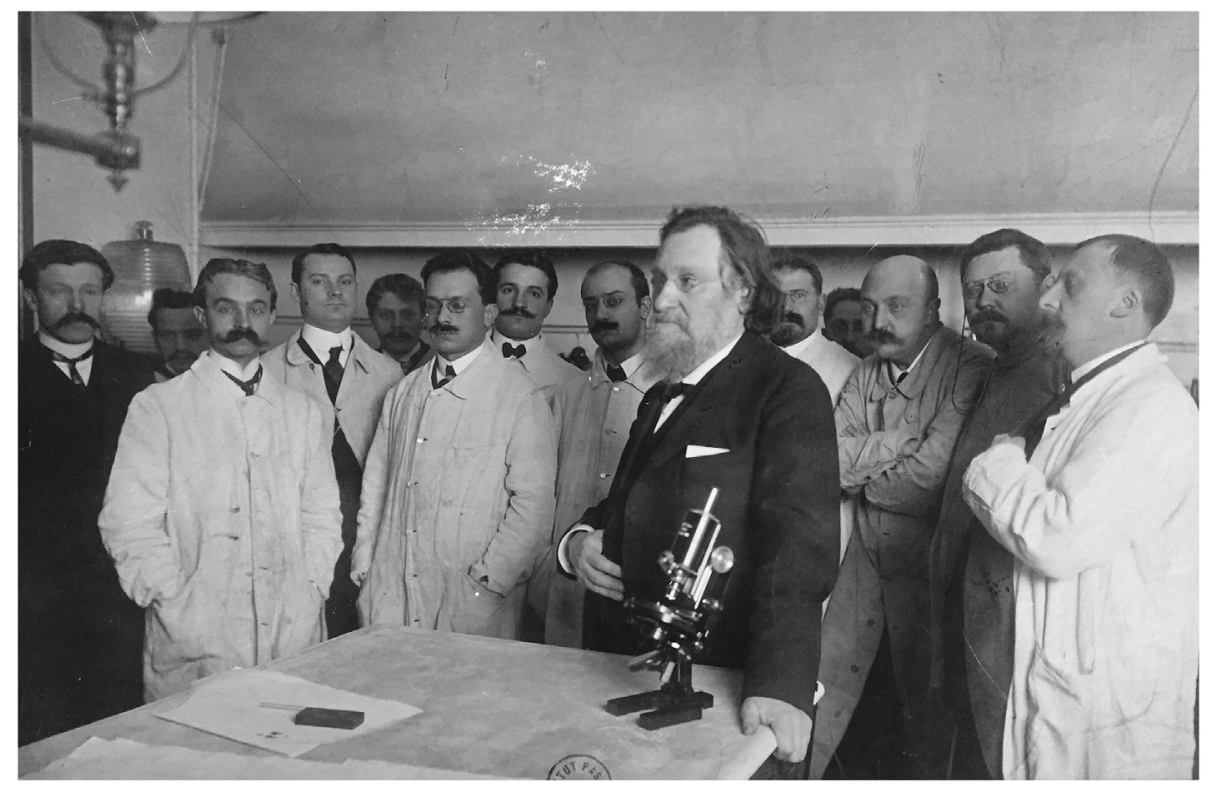

Fig. 7. Metchnikoff and some of his collaborators (Latapie, Levaditi, Besredka, Weinberg, Wollman et Mesnil) around 1905.

Metchnikoff criticized Hans Buchner (1850-1902), another German bacteriologist who was the first to report the presence of a substance (complement) in the blood capable to induce bacteriolysis, «Mr Buchner seeks to establish that leukocytes are attracted by substances extracted from the cadavers of microbes and consequently, the microbes must have already been killed by the bactericidal property of humors before leucocytes move to the invaded area. Leukocytes will therefore intervene only to get ride of the dead microbes, i.e. they play a very secondary role » [44].

Other works of his opponents were more specifically addressed by some of his lieutenants (Fig. 7). For example, Jules Bordet, well known for his work on alexine (complement), spent quite a few years in Metchnikoff's laboratory and published studies that supported phagocytosis and established that it was easily observable in vitro [45]. George Gabritschevsky (1860-1907), a Muscovite microbiologist and epidemiologist who was nominated director of the bacteriologic institute of St Catherine Hospital at the Medicine University (1895-1907), once back in Moscow, fought against Otto Lubarsch (1860-1933) to impose his view on the natural immunity against diphtheria bacilli. In 1894, he demonstrated that in rabbits injected in the aqueous humor with the bacilli, $8 \mathrm{~h}$ later, all bacilli of diphtheria were within phagocytes in immunized rabbits, whereas in non-immunized rabbits there were still free bacteria. Gabritschevsky reported on the processes of leukocytosis, phagocytosis, necrosis, and pinocytosis, a new word he coined to describe the engulfment of soluble substances [46].

Félix Mesnil (1868-1938) was hired as a preparator and secretary of Louis Pasteur and initiated studies in Metchnikoff's laboratory. He showed in guinea pigs injected subcutaneously with Vibrio cholera that the contribution of the direct action of humors on Vibrio in the immunity mechanism was undoubtedly very weak and surpassed by phagocytosis [47]. His demonstration was made to address the so-called Pfeiffer phenomenon. Richard Pfeiffer (1858-1945), a German physician and bacteriologist, had previously claimed that the anti-vibrio immunity was linked to the bactericidal activity of immune sera. In another effort to fight the Pfeiffer phenomenon, Jean Cantacuzène (1863-1934), a Romanian physician and bacteriologist, performed similar experiments in guinea pigs using intraperitoneal injection $[48,49]$. Of interest, in his study, Cantacuzène reported that a narcosis of leukocytes could be induced by an injection of opium, which abolished the process of phagocytosis. Of note, back in Bucharest, Cantacuzène created an institute modeled on the organization of Institut Pasteur.

In 1901, Alexandre Besredka's efforts were directed against the assessments of August Paul von Wasserman (1866-1925), a German bacteriologist and hygienist: "Regarding natural immunity, we know from the researches of M. Metchnikoff and his students at the cost of major persevering efforts that the phagocytic theory could emerge victorious in the fight against the humoral theory. Of course, Wassermann does not take into account the work of the phagocytic school, and considers the question of natural immunity as yet unresolved" [50]. In the same year, Ivan Himmel from Kazan, injecting guinea pigs i.p. with Haemophilus ducreyi (or bacille de Ducrey) reported that by $24 \mathrm{~h}$, most bacilli had been phagocytized [51]. The following year, Himmel reported a similar result using Neisseria gonorrhoeae. After intraperitoneal injection of pus from patients, he showed that guinea pig leukocytes absorb both free gonococci in pus, and human leukocytes packed with gonococci [52]. In the same article, Himmel reported his experiments performed in pigeons and hens. He observed the intracellular digestion of the bacteria and the action of oxygen derived 
free radicals: "If the dead microorganisms engulfed by phagocytes can be only seen after highly colored, they swell and then break up into particles of smaller and smaller, but are still tinted. [...] In living leukocytes, all phagocytized substances are colored with neutral red. The coloration with neutral red depends on the oxidizing properties of phagocytes." Still in 1901, Constantin Levaditi (1874-1953) a Romanian physician who worked with Metchnikoff from 1900 to 1914 , tried to convince the scientific community that polymorphonuclear neutrophils were the source of complement [53]. It was a wrong interpretation of his observation, but one may consider that he was the first to describe something similar to the process of netosis described by Arturo Zychlinsky one hundred years later, in 2004 [54], as his observation was dependent on the death of the cells: "Polynuclear leukocytes altered in their vitality, have a predisposing influence on the bacteriolytic activity of exudative fluid. These leukocytes, once deteriorated spontaneously or under the influence of leukotoxin, release a principle, which, meeting in extracellular fluid exudate, transformed into granules vibrios not engulfed by phagocytes [...] Everything suggests that these destroyed white blood cells, release the complement".

Among the major input in the field and key discoveries was the work of Nicolaï Tchistovitch (1860-1926), a Russian physician from St Petersburg. Before he undertook his investigation with Metchnikoff, it was known that cells within the lung alveoli could trap dust particles (staubzellen/ dust cells). These cells were believed to be epithelial cells. Tchistovitch showed that indeed. the phagocytosis process was performed by alveolar macrophages and not by epithelial cells [55]. Working with rabbit alveolar macrophages, he studied their phagocytic uptake of the bacilli responsible for pig erysipelas (Erysipelothrix rhusiopathiae), sheep anthrax (Bacillus anthracis), and avian cholera (Pasteurella multicoda). ${ }^{3}$ He showed that E. rhusiopathiae and $B$. anthracis were phagocytized but that $P$. multicoda was not. From this observation, in the laboratory of bacteriology of the Medical Military Academia of Saint Petersburg, he coined the word "antiphagin", demonstrating that pneumococci display similar capacity to resist phagocytosis [56]. Quite amazingly, the very first observation made by Tchistovitch on Pasteurella was confirmed almost 100 years later when an outer membrane with antiphagocytic properties was identified [57].

Of note, the presence of foreigners at Institut Pasteur was not appreciated by racist and anti-semitic activists, and in a disgusting book, the French journalist Gustave Téry (1870-1928) refers to "an Institut Pasteur of the wogs" and lampoons the idea of Metchnikoff to abolish old age, stating that the scientists were cheating and inventing false data.

\section{Diapedesis, chemotactism, efferocytosis and opsonisation}

In 1892, Metchnikoff published a book entitled "Leçons sur la pathologie comparée de l'inflammation ${ }^{4}$ » where he had gathered his lectures on the comparative pathology of inflammation delivered at Institut Pasteur in 1891 [42]. Phagocytes were considered to be a part of inflammation, and inflammation was no longer seen only as being a deleterious process but rather as a protective mechanism. Indeed John Hunter (1728-1793) stated nearly one hundred years earlier, in 1794: "Inflammation in itself is not to be considered as a disease, but as a salutary operation, consequent either to some violence or some disease." This concept was poorly recognized, however. Indeed, by the end of the XIXth century, Virchow still considered inflammation to be a dangerous reaction for the host, as a permanent threat for life, and as such, should be opposed by any available means [20].

Metchnikoff defined the role of phagocytes as such: "The broad fact that the invasion of the organism by microbes most often induces, on the one hand, an inflammatory reaction with its associated emigration of leukocytes, and that, on the other hand, the phagocytes are capable of including and destroying the invaders, leads us to admit that the afflux of phagocytes to the invaded region and their bactericidal properties are mechanism which serve to ward off bacterial attack and to maintain the integrity of the organism". Thus, Metchnikoff was well aware of the phenomenon of diapedesis, which had been previously described by others such as the British scientists William Addison (1802-1881) and Augustus Volney Waller (1816-1870), and the German scientist Julius Friedrich Cohnheim (1839-1884), a student of Rudolf Virchow (1821-1902). Indeed it was Cohnheim who demonstrated what Addison hypothesized, namely, that white blood cells cross blood vessels to become pus cells. Metchnikoff reproduced in his book a drawing published in 1875 by Julius Arnold (1835-1915), a German pathologist and former student of Virchow [58], illustrating how leukocytes move across blood vessel walls by passing between endothelial cells at either points of dense staining, "stigmata" or circles of stain, "stomata". One hundred and twenty years later, an amazingly similar picture (in color, this time) was published with highly sophisticated imaging technology [59].

Metchnikoff's team regularly referred to the property of phagocytic cells to move towards the side of infection. The word chemotaxis was coined in 1884 by Wilhelm Pfeffer (1845-1920), a botanist at the University of Tübingen, to describe bacteria swimming towards the vicinity of the tip of a capillary tube filled with a nutrient sugar [60]. The first in vivo observation of this phenomenon was reported in 1889 by Cornelis Adrianus Pekelharing (1848-1922), a Dutch physician, professor of physiological chemistry and histology at the University of Utrecht with experiments performed in frogs [61]. In these experiments, Pekelharing observed that cotton

\footnotetext{
${ }^{4}$ Translated in English in 1893.
}

\footnotetext{
${ }^{3}$ Of note, these were the three types of infections for which Louis Pasteur had successfully developed effective vaccines.
} 
wool soaked with bacteria and introduce into the peritoneal cavity of a frog, contained significantly more leukocytes than those that had been soaked with neutral liquid. In 1890, in Metchnikoff's laboratory, Georges Gabritchevsky arrived at the same conclusion that bacteria produce chemoattractant factor(s). He inserted small capillary tubes filled with saline, or live or dead bacteria under the skin of frogs, rabbits, or axolotl. Twenty-four hours later, the bacteria-filled capillary tubes were full of leukocytes, whereas this was not the case if the capillaries were filled with saline [62]. The same year, Belgium Jean Massart (1865-1925), a doctor in sciences and medicine, working with Charles Bordet, the brother of the famous Jules Bordet, was the first to demonstrate that the host can make chemoattractant factors [63]. In 1891, the same team performed another elegant demonstration. They injected Micrococcus prodigiosus (known as Serratia marcescens today) subcutaneously in a rabbit. Thirty-five minutes later, they sampled the blood and isolated the serum. They then filled capillary tubes with this serum and placed them in the peritoneal cavity of another rabbit. Eight hours later, the capillary tubes were full of leukocytes whereas this was not the case when the tubes were filled with naïve serum. For the first time, they had demonstrated that chemoattractant factors were produced in response to infection [64]. In 1896, Arthur Hugenschmidt (1862-1929), a dentist, sometimes said to be the son of Napoleon III, made in Metchnikoff's laboratory, an interesting observation on the chemotactic properties of saliva using similar approaches with capillary tubes but filled with saliva [65]. This was far before it was recognized that saliva does contain chemokines [66].

How Metchnikoff discovered efferocytosis, as a phenomenon occurring during embryologic development and metamorphosis of amphibian, was previously described [28]. Sir Marc Armand Ruffer (1859-1917) described the phenomenon of efferocytosis by providing cartoons of "macrophage able to swallow microphages (neutrophils) and to destroy and digest them". In his report, he paid tribute to Metchnikoff: "I must be allowed here to thank M. Metchnikoff, under whose direction these investigations have been carried out at the Pasteur Institute in Paris. M. Metchnikoff has not only examined most of my slides, but he, with the greatest kindness, has placed his vast technical and literary knowledge daily at my disposal." [67].

Together with the famous Joseph Lister (1827-1912) who was fully convinced by the phagocyte theory [13], Ruffer was one of the main advocates to defend the concept of phagocytosis in UK. He offered a fitting metaphor to explain phagocytosis: "Should anyone meet a dead lion and find a lamb inside, he, knowing the habits of the lion would not conclude that the lamb had taken refuge in that. True, after a surfeit of lamb, the lion might die of indigestion but the chance of the lamb ever getting out alive would be very small" [68].

Regarding opsonisation and how plasma components (complement or antibodies) favor opsonisation, Metchnikoff compared the phagocytosis process in normal or immunized animal, but he never clearly worded his interpretation of the differences in these two experimental approaches. In fact, he never fully recognized its major role: "The fact that phagocytosis is often "spontaneous", independent from the contribution of opsonins, and the fact that researches on opsonic action have been performed in vitro, outside the body, does not allow to attribute a considerable role to this humoral factor." Metchnikoff preferred the concept of a "stimulin": "A series of new research has created this new chapter of stimulins, substances able to enhance the phagocytic reaction against germs and poisons." [69]. As is often the case in science, the glory went to the one who coined a new word, forgetfulness to the one who made the first discovery. Thus, Sir Edward Almroth Wright (1861-1947) is regularly credited for the discovery of opsonisation in 1903, when he created a neologism from the Greek word "opsono" (opsono) meaning "I prepare victuals for ...", accompanying it with a nice definition, "The body fluids modify bacteria in a manner which renders them a ready prey to phagocytes" [70]. Less well known is Joseph Denys (1857-1932), a professor of bacteriology and anatomy at Louvain University, Belgium, who made the observation, eight years earlier, in 1895, "In vaccinated rabbit, leukocytes get from sera their power to engulf and destroy Streptococcus pyogenes" [71]. Of course creating a new word is not sufficient; one still needs to be the first to do so. Accordingly, Friedrich Neufeld (1869-1945), a physician and bacteriologist who was director of the Robert Koch Institute in Berlin is less well known than Wright for his word "bacteriotropin", a term no longer used to describe the same phenomenon, but proposed one year after Wright [72]. Along a similar theme, the word alexin was created to in 1889 by Hans Buchner (1850-1902) to describe a soluble heat-labile substance present in serum capable of killing bacteria. In 1898, Jules Bordet (1870-1961), a Belgium physician who worked in Metchnikoff's laboratory from 1894 to 1901, discovered that the mechanism of action of hemolytic sera on foreign red blood cells was similar to that by which alexin, in an antimicrobial serum, acts on microbes. These activities were named "complement" by Paul Ehrlich (1854-1915) to indicate that they were complementing the action of antibodies. Bordet moved back to Belgium, created the Institut Pasteur du Brabant and was awarded the Nobel prize in 1919 for his work on complement. It is remarkable that Metchnikoff supported researches in the field of humoral immunity. In addition to the work of Bordet, let's mention the work of Besredka [73], who was the first to describe anti-endotoxin antibodies, when the German school was claiming that such antibodies could not be obtained [19].

Of note, despite their strong opposition, Metchnikoff did respect and admire the German leaders, and both Robert Koch, in 1904, and Paul Erlich, in 1914, made an official visit to Institut Pasteur. And in 1914 Roux and Metchnikoff wrote a most laudatory text on Paul Ehrlich published in French in the German journal Berliner Klinische Wochenschrift [74]. It was just few months before Germany declare war on France!

\section{Investigation of infectious diseases}

In Odessa, in 1888, Nicolai Gamaleia studying the sanitary status of the bird market, identified a new pathology of 
Table 3

Animal species used by Metchnikoff and his lieutenants.

\begin{tabular}{|c|c|c|c|c|c|}
\hline & PHAGOCYTOSIS & $\begin{array}{l}\text { INFECTIOUS } \\
\text { DISEASES }\end{array}$ & AGING & $\begin{array}{l}\text { INTESTINAL } \\
\text { FLORA }\end{array}$ & $\begin{array}{c}\text { GERM FREE } \\
\text { DEVELOPMENT }\end{array}$ \\
\hline Daphnia & $\checkmark$ & $\boldsymbol{\nu}$ & & & \\
\hline Starfish larvae & $\checkmark$ & $\checkmark$ & & & \\
\hline Protozoa & $\checkmark$ & $\checkmark$ & & & \\
\hline Frogs & $\checkmark$ & $\checkmark$ & & & \\
\hline Pigeons & $\checkmark$ & $\checkmark$ & & & \\
\hline Hens & $\checkmark$ & $\checkmark$ & & & \\
\hline Guinea-pigs & $\alpha$ & $\checkmark$ & & & \\
\hline Rabbits & $\nu$ & $\checkmark$ & $\checkmark$ & & \\
\hline Rats & $\checkmark$ & $\checkmark$ & & & \\
\hline Mice & $\checkmark$ & $\checkmark$ & & & \\
\hline Squirrels & $\checkmark$ & $\checkmark$ & & & \\
\hline Spermophilus & $\checkmark$ & $\checkmark$ & & & \\
\hline Sparrows & $\checkmark$ & $\checkmark$ & & & \\
\hline Axolotls & $\checkmark$ & $\checkmark$ & & & \\
\hline Tadpoles & $\checkmark$ & $\checkmark$ & & & $\checkmark$ \\
\hline Flies & & & & & $\checkmark$ \\
\hline Chick & & & & & $\checkmark$ \\
\hline Parrots & & & $\checkmark$ & $\checkmark$ & \\
\hline Dogs & & & $\checkmark$ & $\checkmark$ & \\
\hline Bats & & & & $\boldsymbol{\alpha}$ & \\
\hline Cats & & & & $\alpha$ & \\
\hline Horses & & & & $\checkmark$ & \\
\hline Tortoises & & & & $\boldsymbol{\nu}$ & \\
\hline Rheas & & & & $\checkmark$ & \\
\hline Monkeys & & $\boldsymbol{\nu}$ & & & \\
\hline Caimans & & $\checkmark$ & & & \\
\hline Carps & & $\checkmark$ & & & \\
\hline Goose & & $\checkmark$ & & & \\
\hline Goats & & $\checkmark$ & & & \\
\hline Pigs & & $\checkmark$ & & & \\
\hline Sheeps & & $\checkmark$ & & & \\
\hline Humans & $\checkmark$ & $\boldsymbol{\nu}$ & $\alpha$ & $\checkmark$ & \\
\hline
\end{tabular}

fowl cholera, he called "choleric gastroenteritis of birds" and he isolated the bacillus. Metchnikoff was certainly not a microbiologist, stricto sensu, but his work on phagocytosis of microbes had already a great aura in Odessa and beyond. Thus, Gamaleia named his new microbe "Vibrio metschnikovi". Gamaleia showed that this bacterium was lethal to chickens, pigeons and also guinea pigs. Today this germ can be found in seafood, and in 2014 in Denmark, a septicemia due to Vibrio metschnikovi killed a man of seventy eight. Gamaleia joined Metchnikoff at the Pasteur Institute in 1889, and collaborated with him for the following three years.

With his lieutenants, Metchnikoff studied most infectious diseases that were a threat during the end of the nineteenth century and into the beginning of the twentieth century. Of interest was their quest to find the most appropriate animal model. This is quite different from today, when considerable effort is made to adapt human diseases to mice, despite that they are not always the most appropriate animal model [14]. As summarized in Table 3, rare are the scientists who can boast to have used more than 30 animal species throughout their career. For example, in his attempt to mimic typhoid fever in animals, Metchnikoff and Besredka (Fig. 8) employed 10 Guinea pigs, 24 rabbits, 15 chimpanzees, 1 Gibbon, and 51 other monkeys (Macacus cynomolgus Macacus rhesus, Cynocephalus, Cynopithecus) [75]. The main studies using nonhuman primates were related to syphilis. Between 1903 and 1906, Elie Metchnikoff and Emile Roux (Fig. 8) used more than one hundred apes, particularly chimpanzees and orangutans, to study this human infectious disease. We can easily imagine the sums required for such research. Indeed, Metchnikoff acknowledged that the Institut Pasteur did not have the means to fund such investigation. He was able to carry out his work through an award that had been granted by the municipality of Moscow, and the Osiris prize awarded by the Institute of France to Emile Roux. Metchnikoff was also supported by Varwara Morozov and her husband Ivan Morozov, a wealthy Muscovite industrialist and amateur artist, who was a very generous donor. Five publications in the Annales de l'Institut Pasteur were published by Metchnikoff and Roux, who identified calomel, or mercuric chloride, as an effective therapeutic approach against syphilis. Their work was so convincing that a young medical student, Paul Maisonneuve (1849-1927) came to meet Metchnikoff and Roux, and volunteered his own body 


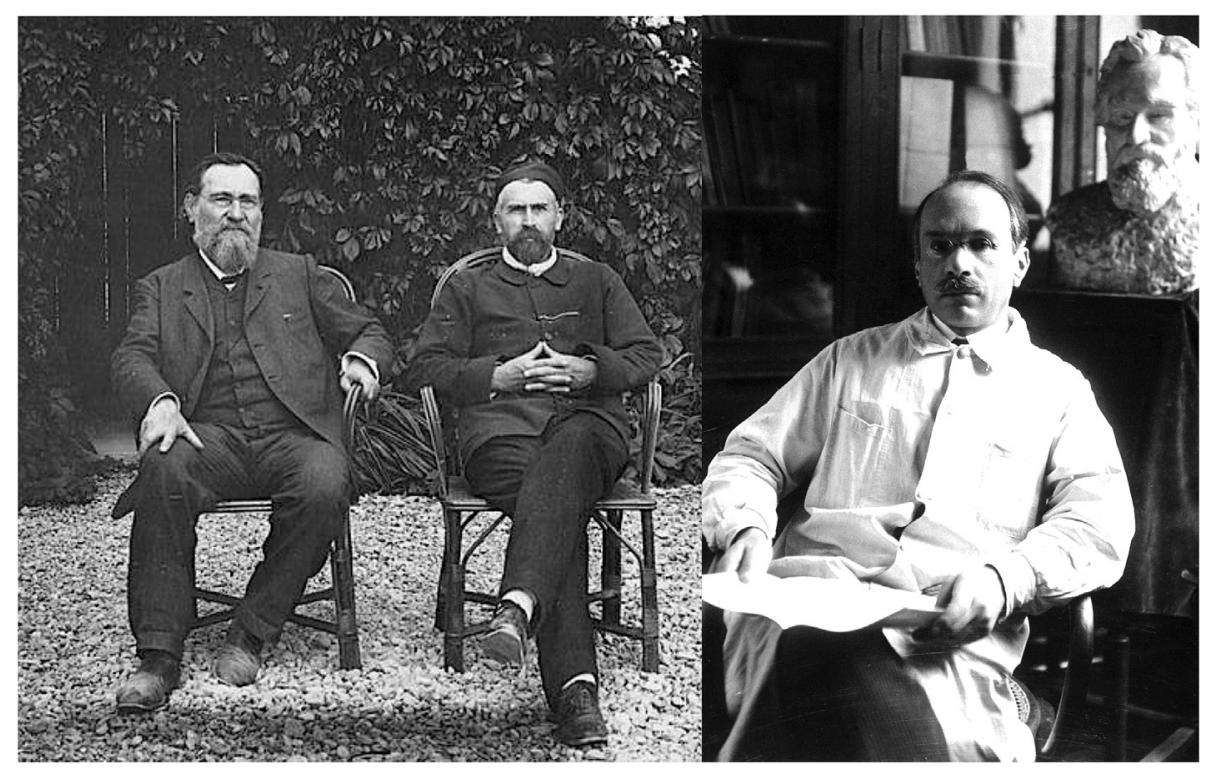

Fig. 8. Left, Elie Metchnikoff with Dr. Emile Roux. Right, Alexandre Besredka in front off a sculpture of Metchnikoff.

to test the effect of calomel after being inoculated with syphilis. After some hesitation, approval was given and the experiment was carried out in the young volunteer and in parallel in chimpanzees and macaques to ensure virulence of the syphilis samples. Maisonneuve swore to having never suffered from syphilis, although in 1900, an estimated $16 \%$ of the population of Paris was afflicted with this venereal disease. Drs Sabouraud, Salmon, and Queyrat followed the volunteer and on February 1st, 1906, two inoculations of samples derived from cankers from two different patients were made on the penis of the young volunteer. An hour later, the penis of Paul Maisonneuve was rubbed for $5 \mathrm{~min}$ with a preparation of calomel. Notably, the monkeys were infected in the eyebrows. For more than three months, Maisonneuve was routinely examined by learned Drs Sabouraud, Salmon, and Queyrat, who inspected the patient's penis with a magnifying glass. Importantly, this experiment demonstrated that work conducted in monkeys could be translated to human medicine and is possibly one of the first examples of bench-to-bedside translational research. Paul Maisonneuve used his experiences to write his medical thesis "Experimental prophylaxis of syphilis". But, it was rumored in the press that Maisonneuve had contracted syphilis, and Dr. Roux had to write to the newspaper "Le Temps" to formally deny such allegations. Of interest, calomel ointment was provided for US soldiers during the last world wars. In Breslau, Albert Neisser (1855-1916), a specialist in sexually transmitted diseases and the discoverer of $N$. gonorrhoeae, sought to reproduce the work of the Parisian scholars but failed. This illustrates an ongoing difficulty of reproducing the work of other scientists, which is a much older crisis than may be appreciated by the scientific community [76-78]. Following the death of Metchnikoff, Institut Pasteur continued to provide researchers with apes, and in 1923, established a chimpanzee breeding facility, the Kindia station $150 \mathrm{~km}$ from Conakry, Guinea. This was the reason why Ilya Ivanovich Ivanov (1870-1932), the Russian specialist in artificial insemination, who wanted to create the first human-ape hybrid contacted the Pasteurians Alexandre Besredka, Emile Roux, and Albert Calmette. This contact allowed him go to Guinea, to undertake his incredible experiment [79]. While ethical considerations of the XXIst century would not support such an initiative, none of the scientists of the beginning of the XXth century were opposed to the experiment. One has to accept that their outlook was quite different and when Metchnikoff refers to Negroes and lower human species, he was speaking within the context of the global vision that humans had at this time.

\section{The quest to understand and delay aging}

Metchnikoff had very specific questions with respect to aging: why does aging occur? Why are senile alterations observed? Why does "old age" vary from species to species? How can we minimize deleterious effects of aging? How can we increase the length of life? Indeed he had an optimistic vision: "It is easy to assume that maybe old age, as we are now seeing it, represents an abnormal form of life against which there would be some remedies to seek". As was often the case in Metchnikoff's work, phagocytes were the main players. Pigmentophages (sometimes also called chromophages) were thought to be responsible for the whitening of hair [80]; myophages were responsible for the degeneration of striated muscle fibers [22]; osteoclasts were rendered responsible for bone resorption [22]; and neuronophages were responsible for the resorption of nervous cells during rabies infection [81] and aging [82]. Some of these hypothese were not favored by the community. For example, Henry de Varigny (1855-1934), a French scientific journalist, published (January, 25th, 1905) an article in "Le Temps", in which he states that "Neurophagy" does not exist. He referred to the 
work of Georges Marinesco (1863-1938), a famous Romanian neurologist who never observed such "Metchnikovian" cells. Nevertheless, Metchnikoff was not that far from the truth. Studies by electron microscopy comparing brain areas of young and old rhesus monkeys showed dense inclusions in a limited number of astrocytes of young animals and in a greater number in older animals [83]. Additionally, in young animals, microglial cells contain few small inclusions but in older animals, nearly all microglial cells are found to contain numerous large electron dense inclusions [83]. Microglial cells regulate adult neurogenesis and under basal conditions, apoptotic corpses of newly generated neurons are rapidly phagocytized [84]. Phagocytosis by the microglial cells is increased with age and inflammatory stimuli. Over-activated microglial cells can be neurotoxic and contribute to neurodegeneration. Microglia senescence appears to underlie the switching of microglia from neuroprotective in the young brain to neurotoxic in the aged brain [85]. Neher et al. reported that dying neurons are quickly removed through phagocytosis by microglial cells. During inflammation, microglial cells execute neuronal death through phagocytosis of neurons that are otherwise viable [86].

Metchnikoff wondered why phagocytes were activated during aging. What events in aging people cause the global alteration? The gut was declared to be the culprit, and Metchnikoff and his lieutenants studied the intestinal structure and content of a large number of species from bat [87] to horses [88], cats [89] and humans [90,91]. Metchnikoff states: "The human digestive tract contains three species of microbes of putrefaction [...]. These microbes are able to produce poisons. We feed in our digestive tract what cause our chronic poisoning [...]. There is a link between the gut flora and the senile degeneration". He identified bacteria in human feces and in intestinal content obtained from cadavers (Bacillus putrificus, Bacillus sporogenes, Bacillus welchii (Clostridium perfringens)), each of which is able to produce toxins. Given per os to a monkey, these bacteria do not induce significant illness, but the filtered cultures of the bacteria injected intravesically into a rabbit killed the animals [91]. This idea ran contrary to the concept supported by Heinrich Finkelstein (1865-1942), a German born pediatrician who claimed that newborn intestinal diseases were only due to food toxicity but were not of microbial origin. Metchnikoff identified paracresol as a toxin produced by intestinal bacteria, which hastened aging, induced atheromatous plaques in rabbits, liver injury and death in guinea pigs, lesions of brain vasculature, and alteration of liver and kidneys in macaques [92]. Indol was another poison identified to induce atheromatous lesions and liver and kidney alteration similar to those observed in aged humans. A German professor of pathology, Hugo Ribbert (1855-1920) opposed Metchnikoff's vision: "The idea is vain, without any scientific basis and it is inconceivable that intestinal poisons can be absorbed regularly". But Metchnikoff was correct. In fact others, such as Charles Bouchard (1837-1915) in France, Sir William Arbuthnot Lane (1856-1943) in UK, and later John Harvey Kellogg (1852-1943) in USA were supporters of the concept of auto- intoxication [93]. Recently, the group of Gregory Hazen in Cleveland has demonstrated that the gut flora releases trimethyl amine which alters liver bile acid and sterol metabolism and is transformed by the hepatic flavin-containing monooxygenase into trimethylamine $\mathrm{N}$-oxide (TMAO) that favors the formation of atheromatous plaques [94]. This group further showed that gut microbial transplantation could transmit atherosclerosis susceptibility [95]. TMAO has also been shown to directly contribute to platelet hyperreactivity and enhanced thrombosis potential [96]. Furthermore, small molecules, similar to those used by Metchnikoff, have been confirmed to be released by gut microbiota [97]. Convinced by the negative effect of the gut, comparing the life expectancy of humans, parrots, tortoises, or elephants with that of many other species, Metchnikoff arrived at the conclusion, "The longer is the large intestine, the shorter is the life!" [20].

To delay aging, Metchnikoff proposed the use of probiotics. Metchnikoff believed that the harmful effects of toxins produced by intestinal bacteria could be replaced by beneficial lactic acid bacteria. His wife Olga wrote, "His hypothesis seemed confirmed by the fact that the great longevity of populations that feed almost exclusively with sour milk. Notably in Bulgaria, there are entire villages, known for the longevity of their inhabitants. Based on these considerations, he experimented on himself and systematically introduced in his diet sour milk, prepared with pure cultures of some lactobacilli. It has a beneficial effect on his health and we followed his example. Some doctors advocated sour milk and its use spread gradually" [16]. Metchnikoff required that his gut would be examined after his death. With some childish credulity, Metchnikoff described an elderly Caucasus woman Ossétine Thense Abalva, whose age was estimated to be about 180 years old. Her main food was barley bread with buttermilk obtained after churning the cream.

Metchnikoff published his consideration on the role of lactobacilli in prolonging life in 1907 [98] after the discovery of the Lactobacillus bulgaricus by a young Bulgarian doctor and microbiologist, Stamen Grigorov (1878-1945). After high school in Sofia, Grigorov initiated natural science studies in Montpellier before joining Geneva where he completed his medical studies and worked in the laboratory of Léon Massol (1838-1909), professor of bacteriology at University of Geneva. Massol, impressed by the talents of the young Bulgarian, offered him an assistantship. Prof. Massol, born in Paris, was an engineer from the École Polytechnique who initially worked in a railway company before he got excited about bacteriology, trained at Institut Pasteur, and got the bacteriology Chair in the faculty of Sciences of Geneva in 1900. He became the official bacteriologist of the city of Geneva in charge of water quality. Massol, aware of the interest of Metchnikoff to discover the secrets of longevity, wrote him about the discovery of L. Bulgaricus in his laboratory by Grigorov. Metchnikoff invited the two men to Paris and proposed that Grigorov give a lecture at the Institut Pasteur. Grigorov had brought with him the precious Bulgarian yoghurt in a "rukatka", a type of Bulgarian pottery used to continue the precious beverage. To test his ideas, Metchnikoff 
performed experiments mainly in rats. Using standard food supplemented with another probiotic, Glycobacter peptolyticus, he observed that phenol and indoxyl levels were reduced in urine. He performed the experiment on himself and observed the same positive effect [99]. Of note, nearly a hundred years later, a New Zealand team has shown that a steady diet with probiotics (Bifidobacterium lactis) for three weeks in the elderly, improves the phagocytic capacity of their neutrophils and monocytes [100]. In addition, interestingly, it has recently been reported that lactic acid bacteria can regulate emotional behavior, and the authors conclude that probiotics may be useful therapeutic adjuncts in anxiety and depression [101]. This may explain why Metchnikoff's own mental health status improved over time.

\section{The philosopher}

Metchnikoff was more of a thinker than a philosopher even if one of his books is entitled "optimist philosophy". Besredka defines of Metchnikoff as a thinker and philosopher, "He is not a man to hover for a long time in the metaphysical sphere. He feels secure when he is on the solid ground of experimentation. For him, the philosopher rapidly gives way to the man of the bench." [20]. Metchnikoff was well educated in philosophy as well as science, however. When addressing pessimism, he could cite the Ecclesiastes, the Buddhism doctrine, famous philosophers and writers such Hegesias of Cyren, Schopenhauer, Karl von Hartmann, Goethe, Kant, Voltaire, Poushkin, and Giacomo Leopard, but he was also aware of the less popular works of Pavel Ivanovič Kovalevskij (1850-1923), a physician and professor of mental and nervous diseases in Kharkhov.

For Metchnikoff, reasoning found its foundation in scientific knowledge provided by scientists. Even at a very young age, he read Darwin's concepts of evolution. His vision of humanity and life and his questioning were informed by factual observations. Metchnikoff, as an embryologist, supported the simian origin of humans. Metchnikoff shared with Darwin admiration of the harmony between the insects and the orchids, how the flower offers its nectar to the insects while they, in turn, contribute to the fertilization of the plants. But Metchnikoff also listed the elements of disharmony of the human body such as the appendix, body hair, wisdom teeth, the hymen, onanism, and the limited usefulness of the large intestine. $\mathrm{He}$ also considered that pathologic aging and the failure to reach the instinct of natural death is the greatest disharmony of human nature.

Despite the titles of his books referring to optimism [22,25], Metchnikovian optimism is very much limited to the expectation that science will help to solve human problems. From a depressed young adult, he became a wise aged person. He spoke about himself in a modest way, "I know quite intimately a scientist who felt very unhappy in his youth. Blessed with a kind of hypersensitivity to pain, he tried to calm it by any means. Any annoyance was able to dive in a real state of prostration in which he remedied by narcotics. To escape certain moral pain, he inoculated himself with morbid virus.
Later at mature and advanced age, his hypersensitivity gave way to less acute feelings. He no longer feels bad in such a violent manner that during his youth. In contrast, he appreciates much better the positive side of life and, even in cases where he feels unhappy, he never comes to him the idea of shortening its existence. Being young, he was pessimistic and admitted that the bad far outweighs the good. At a more advanced age, his assessment of the existence has totally changed."

After reading Schopenhauer's "Studies in pessimism", and looking into the text of Faust, and studying the life of his author, Goethe, he arrived at the conclusion that the pessimism he knew as a young adult was shared by others, but love of life and optimism come with the wisdom of aged people. He was also convinced that there are close relations between intellectual activity and sexual functions. Was his motivation to address syphilis due to some personal interest? "The certainty of safety from this disease [syphilis] might render extraconjugal relationship more frequent." [22]. Did he see for himself some similarities with Faust? He wrote: "Faust is a young, learned man who expects too much from science and life and whose genius requires extra-conjugal love as a stimulant; he is unbalanced and inevitably pessimistic.". He recalled that Faust attempted to kill himself, before moving later towards optimism [22].

He shared with Leon Tolstoy, his concerns about death, but fully disagree when Tolstoy considered that science cannot offer a solution to the principal problem of humanity and understanding of the sense of life. No doubt that their encounter in Tolstoy's home, Yasnaya Polyana, on May, 30th, 1909 was the source of a lively discussion but failed to end with any consensus between these two individuals. Metchnikoff was an ardent believer in Science and thought that Science did not have the recognition it deserves in modern society: "Any ideal that may be capable of uniting mankind in some religion of the future must be based on scientific principles, and if, as we are told, it is impossible to live without faith then that faith can only be faith in the power of science." [17].

\section{Conflict of interest statement}

None to declare.

\section{Acknowledgments}

The authors thank their colleagues from the Centre de Ressources en Information Scientifique, the Archives, the photothèque and the museum of Institut Pasteur for their help and support. They express their deep gratitude to Juris Salaks, deputy director of the Pauls Stradinš Museum of the History of Medicine, (Riga, Latvia). The authors thank Dr. Molly Ingersoll for English editing. All pictures have been reproduced with the kind authorization of Institut Pasteur, the Russian Academy of Science (Moscow) and the Pauls Stradiňš Museum of the History of Medicine (Riga, Latvia). 
Of note, a complete bibliography of Metchnikoff is available at http://webext.pasteur.fr/biblio/ressources/histoire/ metchnikoff.php\#1.

\section{References}

[1] Tauber AI, Chernyak L. Metchnikoff and the origins of immunology: from metaphor to theory. New York and Oxford: Oxford University Press; 1991.

[2] Tauber AI. The birth of immunology: III. The fate of the phagocytosis theory. Cell Immunol 1992;139:505-30.

[3] Chernyak L, Tauber AI. The idea of immunity: Metchnikoff's metaphysics and science. J Hist Biol 1990;23:187-249.

[4] Tauber AI, Chernyak L. The birth of immunology. II. Metchnikoff and his critics. Cell Immunol 1989;121:447-73.

[5] Bested AC, Logan AC, Selhub EM. Intestinal microbiota, probiotics and mental health: from Metchnikoff to modern advances: part I autointoxication revisited. Gut Pathog 2013;5:5.

[6] Cavaillon JM. The historical milestones in the understanding of leukocyte biology initiated by Elie Metchnikoff. J Leukoc Biol 2011;90: 413-24.

[7] Gordon S. Elie Metchnikoff: father of natural immunity. Eur J Immunol 2008;38:3257-64.

[8] Kaufmann SH. Immunology's foundation: the 100-year anniversary of the Nobel prize to Paul Ehrlich and Elie Metchnikoff. Nat Immunol 2008;9:705-12.

[9] Silverstein AM. Darwinism and immunology: from Metchnikoff to burnet. Nat Immunol 2003;4:3-6.

[10] Tauber AI. Metchnikoff and the phagocytosis theory. Nat Rev Mol Cell Biol 2003;4:897-901.

[11] Zeiss HEM, Leben und Werk. Elias Metschnikow, Leben und Werk. Jena: Fischer: Paul-Ehrlich-Institut; 1932.

[12] Petrov R, Ulyankina T. The genius of E. E. Metchnikoff : discoveries over the centuries. Biosci Rep 1996;16:189-205.

[13] Vikhanski L. Immunity. How Elie Metchnikoff changed the course of modern medicine. Chicago Review Press; 2016.

[14] Warren HS, Fitting C, Hoff E, Adib-Conquy M, Beasley-Topliffe L, Tesini B, et al. Resilience to bacterial infection: difference between species could be due to proteins in serum. J Infect Dis 2010;201: 223-32.

[15] Cahanesco. Contribution à l'étude de l'auto-purificationmicrobienne du vagin. Expériences sur les animaux. Ann Inst Pasteur 1901;13:842-56.

[16] Metchnikoff O. La vie d'Élie Metchnikoff. Librairie Hachette; 1920.

[17] Brandreth C. The man who prolongs life, vol. XXIII. London Magazine; 1910. p. 578-84.

[18] Roux E. Jubilé du Professeur Elie Metchnikoff - lettre de M. E. Roux. Ann Inst Pasteur 1915;29:358-63.

[19] Rietschel ET, Cavaillon JM. Richard Pfeiffer and Alexandre Besredka: creators of the concept of endotoxin and anti-endotoxin. Microbes Infect 2003;5:1407-14.

[20] Besredka A. Histoire d'une idée. L'oeuvre de Metchnikoff. Paris: Masson \& Cis; 1921.

[21] Tauber AI. Introduction. Dordrecht, Boston, London: Kluwer Academic Publishers; 2000.

[22] Metchnikoff E. Essais optimistes. Paris: A. Maloine; 1907.

[23] Metchnikoff O. Note sur l'influence des microbes dans le développement des têtards. Ann Inst Pasteur 1901;1901:631-4.

[24] Metchnikoff E, Burnet E, Tarassevitch L. Recherches sur l'épidémiologie de la tuberculose dans les steppes des Kamoulks. Ann Inst Pasteur 1911;25:785-804.

[25] Metchnikoff E. Etudes sur la nature humaine : essai de philosophie optimiste. Paris: Masson \& Cis; 1904.

[26] Ecker E. Ueber die veränderungen, welche die blutkörperchen in der milz erleiden. Z Ration Med 1847;6:206.

[27] Lieberkühn N. Ueber Bewegungserscheinungen der zellen. Marburg und Leipzig; 1870.
[28] Cavaillon JM. Sir Marc Armand Ruffer and Giulio Bizzozero: the first reports on efferocytosis. J Leukoc Biol 2013;93:39-43.

[29] Bizzozero G. Studi sulla struttura delle ghiandole linfatiche. Giornale della R Accad Med Torino 1873:13:132-44.

[30] Panum PL. Das putride Gift, die Bakterien, die putride Infektion oder Intoxication und die Septikämie. Arch Path Anat Physiol Klin Med (Virchow's Archive) 1874;60:301-52.

[31] Osler W. On the pathology of miner's lung. Can Med Surg J 1875;4: 145-69.

[32] Koch R. Untersuchungen ueber Bakterien V. Die Aetiologie der Milzbrand-Krankheit, begruendent auf die Entwicklungsgeschichte des Bacillus Anthracis. Beitr Z Biol D Pflanz 1876;2:277-310.

[33] Grawitz PA. Beiträge zur systematischen Botanik der pflanzlichen Parasiten mit experimentellen Untersuchungen über die durch sie bedingten Krankheiten. Arch Pathol Anat Physiol Klin Med 1877;70: $546-8$.

[34] Roser W. Beitragen zur Biologie niederster Orgabismen. (Marburg). 1881.

[35] Ogston A. Report upon micro-organisms in surgical diseases. Brit Med J 1881 March 12:369-75.

[36] Metchnikoff E. Untersuchungen uber die intracelluläre verdauung bei wirbellosen thieren. Arb. Zool. Inst. Univ. Wien; 1884. p. 5.

[37] Metchnikoff E. Unterchungen über die mesodermalen phagocyten einiger wirbeltiere. Biol Cent 1883;3(18):560-5.

[38] Metchnikoff E. Über eine sprosspilzkrankheit der daphnien; Beitrag zur über den kamp der phagocyten gengen krankheitserreger. Arch Pathol Anat Physiol Klin Med 1884;96:177-95.

[39] Metchnikoff E. Ueber die beziehung der phagocyten zu milzbrandbacillen. Arch Pathol Anat Physiol Klin Med 1884;97:502-7.

[40] Dubos RJ. The micro-environment of inflammation or Metchnikoff revisited. Lancet 1955;269:1-5.

[41] Metchnikoff E. L'état actuel de la question de l'immunité (Rapport au congrès international de Budapest). Ann Inst Pasteur 1894;8:706-21.

[42] Metchnikoff E. Leçons sur la pathologie comparée de l'inflammation. Paris: Masson; 1892.

[43] Metchnikoff E. Etudes sur l'immunité. Ann Inst Pasteur 1890;4: 193-212.

[44] Metchnikoff E. La théorie des phagocytes au congrès hygiénique de Londres. Ann Inst Pasteur 1891;5:534-42.

[45] Bordet J. Recherches sur la phagocytose. Ann Inst Pasteur 1889;10: 104-18.

[46] Gabritschewsky G. Du rôle des des leucocytes dans l'infection diphtérique. Ann Inst Pasteur 1894;8:673-95.

[47] Mesnil F. Sur le mécanisme de l'immunité contre la septicémie vibrionienne. Ann Inst Pasteur 1896;10:369-86.

[48] Cantacuzène J. Mode de destruction du vibrion cholérique dans l'organisme. Contribution à l'étude du problème de l'immunité. Thèse de Médecine (Paris). 1894.

[49] Cantacuzène J. Nouvelles recherches sur le mode de destruction des vibrions dans l'organisme. Ann Inst Pasteur 1898;12:273-300.

[50] Besredka A. Etude de l'immunité dans l'infection typhique expérimentale. Ann Inst Pasteur 1901;15:209-31.

[51] Himmel J. Contribution à l'étude de l'immunité des animaux vis à vis du bacille du chancre mou. Ann Inst Pasteur 1901;15:928-40.

[52] Himmel J. Le rouge neutre (neutralroth). Son rôle dans l'étude de la phagocytose eb général et celle de la blennorrhagie en particulier. Ann Inst Pasteur 1902;16:663-85.

[53] Levaditi C. Sur l'état de la cytase dans le plasma des animaux normaux et des organismes vaccinés contre le vibrion cholérique. Ann Inst Pasteur 1901;15:894-927.

[54] Brinkmann V, Reichard U, Goosmann C, Fauler B, Uhlemann Y, Weiss DS, et al. Neutrophil extracellular traps kill bacteria. Science 2004;303:1532-5.

[55] Tchistovitch N. Des phénomènes de phagocytose dans les poumons. Ann Inst Pasteur 1889:3:337-61.

[56] Tchistovitch N, Yourevitch V. Sur les opsonines et les antiphagines dans l'infection pneumococcique. Ann Inst Pasteur 1908;22:611-5. 
[57] Truscott WM, Hirsh DC. Demonstration of an outer membrane protein with antiphagocytic activity from Pasteurella multocida of avian origin. Infect Immun 1988;56:1538-44.

[58] Arnold J. Uber das verhalten der wandungen der blutgefasse bei der emigration weisser blutkorper. Virchows Arch A Pathol Anat Pathol 1875;62:487-503.

[59] Proebstl D, Voisin MB, Woodfin A, Whiteford J, D'Acquisto F, Jones GE, et al. Pericytes support neutrophil subendothelial cell crawling and breaching of venular walls in vivo. J Exp Med 2012;209: 1219-34.

[60] Pfeffer W. Lokomotorische Richtungsbewegungen durchchemische Reize. Untersuchungen Bot Inst Tüb 1884;1:363-482.

[61] Pekelharing CA. Chemotactische werking van miltvuurbacillen op leucocyten van den kikvorsch. Handel het Nederl Nat. geneesk Congr Leiden 1889;2:125-8.

[62] Gabritchevsky G. Sur les propriétés chimiotactiques des leucocytes. Ann Inst Pasteur 1890;4:346-62.

[63] Massart J, Bordet C. Recherches sur l'irritabilité des leucocytes. J de Médecine de Chir de Pharmacol 20 février 1890.

[64] Massart J, Bordet C. Le Chimiotactisme des leucocytes et l'infection microbienne. Ann Inst Pasteur 1891;5:417-44.

[65] Hugenschmidt A. Etudes experimentales des divers procédés de défense de la cavité buccale contre l'invasion des bactéries pathogènes. Ann Inst Pasteur 1896;10:545-66.

[66] Khan A. Detection and quantitation of forty eight cytokines, chemokines, growth factors and nine acute phase proteins in healthy human plasma, saliva and urine. J Proteomics 2012;75:4802-19.

[67] Ruffer M. On the phagocytes of the alimentary canal. Quaterly J Microsc Sci 1890;30:481-93.

[68] Ruffer M. Remarks made at the discussion on phagocytosis and immunity at the Pathological Society of London. Brit Med J March 15th, 1892;XX:591-6.

[69] Metchnikoff E. Les phagocytes en chirurgie (preface). Dr. Raymond Petit; 1915.

[70] Wright EA, Douglas SR. An experimental investigation on the role of the blood fluids in connection with phagocytosis. Proc R Soc (London) 1903;72:357-70.

[71] Denys J, Leclef J. Sur le mécanisme de l'immunité. La Cellule. Recueil de Cytol d'Histologie générale 1895;11:175-221.

[72] Neufeld F, Rimpau W. Über die antikörper des Streptokokken und Pneumokokken immunserums. Dtsch Med Wochenschr 1904;40: 1458-60.

[73] Besredka A. De l'anti-endotoxine typhique et des anti-endotoxines, en général. Ann Inst Pasteur 1906;20:149-54.

[74] Roux E, Metchnikof E. L'oeuvre de Paul Ehrlich. Berl Klin Wochenschr 1914:51:529-31.

[75] Metchnikoff E, Besredka A. Recherches sur la fièvre typhoide expérimentale. Ann Inst Pasteur 1911;25:193-221.

[76] Prinz F, Schlange T, Asadullah K. Believe it or not: how much can we rely on published data on potential drug targets? Nature reviews. Drug Discov 2011;10:712.

[77] Freedman LP, Cockburn IM, Simcoe TS. The economics of reproducibility in preclinical research. PLoS Biol 2015;13:e1002165.

[78] Scannell JW, Bosley J. When quality beats quantity: decision theory, drug discovery, and the reproducibility crisis. PLoS One 2016;11:e147215.

[79] Rossiianov K. Beyond species: Il'ya Ivanov and his experiments on cross-breeding humans and anthropoid apes. Sci context 2002;15: 277-316.
[80] Metchnikoff E. Etudes biologiques sur la vieillesse. I. Sur le blanchiment des cheveux et des poils. Ann Inst Pasteur 1901;15:865-79.

[81] Manouélian Y. Recherche sur le mécanisme de la destruction des cellules nerveuses. Ann Inst Pasteur 1906;20:859-68.

[82] Metchnikoff E. Etudes biologiques sur la vieillesse. II Recherche sur la vieillesse des perroquets. Ann Inst Pasteur 1902;16:912-7.

[83] Peters A, Josephson K, Vincent SL. Effects of aging on the neuroglial cells and pericytes within area 17 of the rhesus monkey cerebral cortex. Anatomical Rec 1991;229:384-98.

[84] Sierra A, Encinas JM, Deudero JJ, Chancey JH, Enikolopov G, Overstreet-Wadiche LS, et al. Microglia shape adult hippocampal neurogenesis through apoptosis-coupled phagocytosis. Cell Stem Cell 2010; 7:483-95.

[85] Luo XG, Ding JQ, Chen SD. Microglia in the aging brain: relevance to neurodegeneration. Mol Neurodegener 2010;5:12.

[86] Neher JJ, Neniskyte U, Zhao JW, Bal-Price A, Tolkovsky AM, Brown GC. Inhibition of microglial phagocytosis is sufficient to prevent inflammatory neuronal death. J Immunol 2011;186:4973-83.

[87] Metchnikoff E, Weinberg. Pozerski, Distaso, Berthelot. Roussettes et microbes. Ann Inst Pasteur 1909;23:937-78.

[88] Choukévitch j. Etude de la flore bactérienne du gros intestin du cheval. Ann Inst Pasteur 1911;25:345-67.

[89] Wollman E. Action des l'intesting grêle sur les microbes. Ann Inst Pasteur 1910;24:807-17.

[90] Tsiklinsky PV. Sur la flore microbienne termophile du canal intestinal de l'homme. Ann Inst Pasteur 1903;17:217-40.

[91] Metchnikoff E. Etudes sur la flore intestinale. Ann Inst. Pasteur 1908; 22:929-55.

[92] Metchnikoff E. Poisons intestinaux et scléroses. Ann Inst. Pasteur 1910; 24:755-70.

[93] Podolsky S. Cultural divergence: Elie Metchnikoff's Bacillus bulgaricus therapy and his underlying concept of health. Bull Hist Med 1998;72:1-27.

[94] Wang Z, Klipfell E, Bennett BJ, Koeth R, Levison BS, Dugar B, et al. Gut flora metabolism of phosphatidylcholine promotes cardiovascular disease. Nature 2011;472:57-63.

[95] Gregory JC, Buffa JA, Org E, Wang Z, Levison BS, Zhu W, et al. Transmission of atherosclerosis susceptibility with gut microbial transplantation. J Biol Chem 2015;290:5647-60.

[96] Zhu W, Gregory JC, Org E, Buffa JA, Gupta N, Wang Z, et al. Gut microbial metabolite TMAO enhances platelet hyperreactivity and thrombosis risk. Cell 2016;165:111-24.

[97] Donia M, Fischbach M. Small molecules from human microbiota. Science 2015;349:395.

[98] Metchnikoff E. Quelques remarques sur le lait aigre. Revue générale de chimie pure appliquée 1907;10:77-8.

[99] Metchnikoff E, Wollman E. Sur quelques essais de désintoxication intestinale. Ann Inst Pasteur 1912;26:825-49.

[100] Gill HS, Rutherfurd KJ, Cross ML, Gopal PK. Enhancement of immunity in the elderly by dietary supplementation with the probiotic Bifidobacterium lactis HN019. Am J Clin Nutr 2001;74:833-9.

[101] Bravo JA, Forsythe P, Chew MV, Escaravage E, Savignac HM, Dinan TG, et al. Ingestion of Lactobacillus strain regulates emotional behavior and central GABA receptor expression in a mouse via the vagus nerve. Proc Natl Acad Sci U S A 2011;108: $16050-5$. 